\title{
Dace Bērtule
}

\section{BĒRNU AR CEREBRĀLO TRIEKU ĢIMEN̦U VAJADZĪBAS UN TĀS IETEKMĒJOŠIE FAKTORI}

Promocijas darba kopsavilkums medicinas doktora zinātniskā grāda iegūšanai Specialitāte - fizikālā un rehabilitācijas medicina 


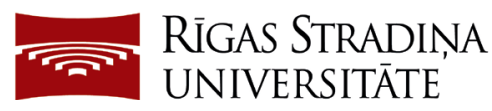

\author{
Dace Bērtule
}

\title{
BĒRNU AR CEREBRĀLO TRIEKU ĞIMEN̦U VAJADZĪBAS UN TĀS IETEKMĒJOŠIE FAKTORI
}

\author{
Promocijas darba kopsavilkums \\ medicīnas doktora zinātniskā grāda iegūšanai
}

Specialitāte - fizikālā un rehabilitācijas medicīna

$$
\text { Rīga, } 2018
$$


Promocijas darbs izstrādāts: Rīgas Stradina universitātē

Darba zinātniskā vadītāja:

Dr. med. asociētā profesore Anita Vētra

Rīgas Stradina universitāte, Latvija

Oficiālie recenzenti:

Dr. med. profesors Jānis Vētra

Rīgas Stradina universitāte, Latvija

Dr. med. profesors Valdis Folkmanis

Latvijas Universitāte

Asociētā profesore Katrina Bannigan

Plimutas universitāte, Apvienotā Karaliste

Promocijas darba aizstāvēšana notiks 2018. gada 30. augustā plkst. 15.00 Rīgas Stradiña universitātes Medicīnas promocijas padomes atklātā sēdē Rīgā, Anniņmuižas bulv. 26a, Medicīnas izglìtības tehnologiju centra konferenču zālē

Ar promocijas darbu var iepazīties RSU bibliotēkā un RSU tīmekḷa vietnē: www.rsu.lv.

Promocijas padomes sekretāre:

Dr. med. asociētā profesore Inese Gobiṇa 


\section{SATURS}

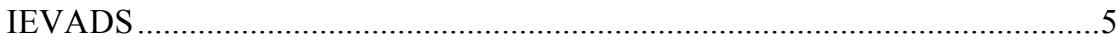

Promocijas darba mērksis .................................................................... 6

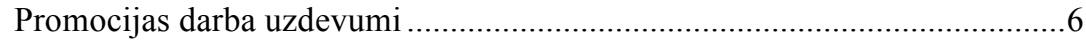

Promocijas darba hipotēze .....................................................................

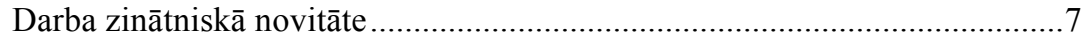

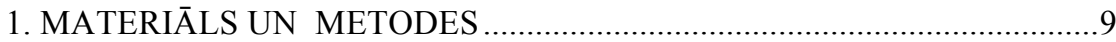

1.1. Bērnu ar cerebrālo trieku g̊imeņu vajadzības ietekmējošo ......................9

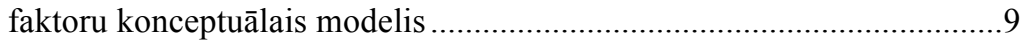

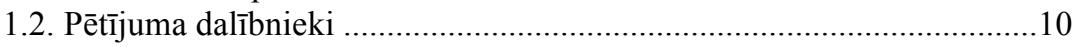

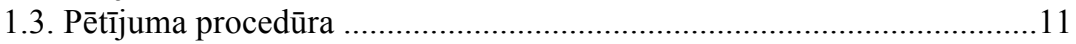

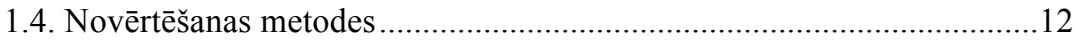

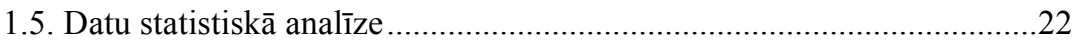

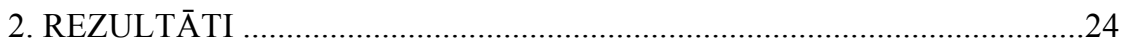

2.1. Pētāmās grupas raksturojums .................................................................24

2.2. Rehabilitācijas pieejamības un pakalpojumu saņemšanas kārtības

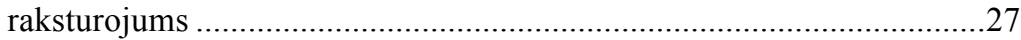

2.3. Aprūpes procesa novērtējuma rezultāti ..............................................27

2.4. Ģimen̦u vajadzības aptaujas rezultāti...................................................27

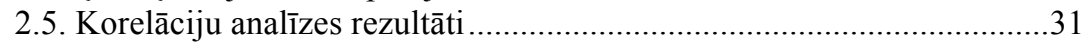

2.6. Daudzfaktoru lineārās regresijas analīzes rezultāti ...................................34

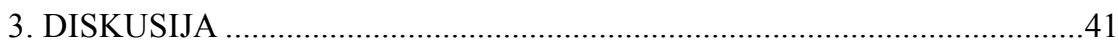

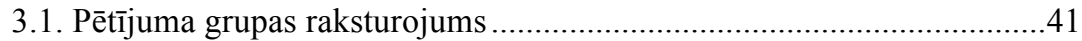

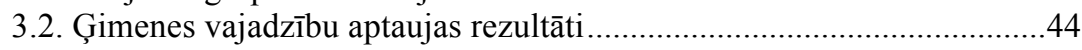

3.3. Bērnu ar cerebrālo trieku raksturojošo faktoru saistība ar gimenes

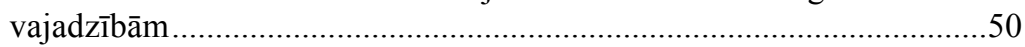

3.4. Ģimeni raksturojošo faktoru saistība ar gimenes vajadzībām ...............53

3.5. Rehabilitācijas pakalpojumus raksturojošo faktoru saistība ar gimenes vajadzībām.

3.6. Bērnu ar cerebrālo trieku gimen̦u vajadzības izskaidrojošo faktoru analīze.

3.7. Metodologiskā analīze un pētījuma ierobežojumi ................................65

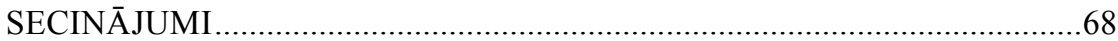

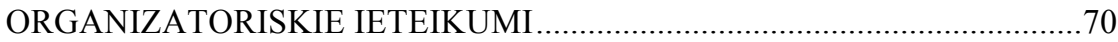

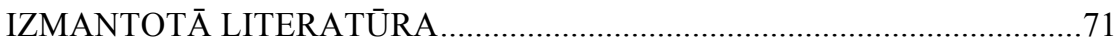

PUBLIKĀCIJAS UN ZIN̦OJUMI PAR PĒTĪJUMA TĒMU ...........................76

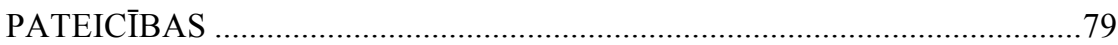




\section{LIETOTIE SAĪSINĀJUMI}

$\begin{array}{ll}\text { PVO } & \text { Pasaules Veselības organizācija } \\ \text { LR } & \text { Latvijas Republika } \\ \text { CSP } & \text { Centrālā statistikas pārvalde } \\ \text { MK } & \text { Ministru kabinets } \\ \text { VDEĀK } & \text { Veselības un darbspēju ekspertīzes ārstu valsts komisijas } \\ \text { LMFKS } & \text { Lielo motoro funkciju klasifikācijas sistēma } \\ \text { KFKS } & \text { Komunikācijas funkciju klasifikācijas sistēma } \\ \text { ĢVA } & \text { Ģimenes vajadzību aptauja } \\ \text { APN-20 } & \text { Aprūpes procesa novērtējums } \\ \text { ĢAS } & \text { Ģimenes atbalsta skala } \\ \text { USS } & \text { Uztvertā stresa skala }\end{array}$




\section{IEVADS}

Cerebrālā trieka ir biežākais fiziskas nespējas iemesls bērnu vecumā ar potenciāli negatīvu ietekmi ne tikai uz paša bērna, bet arī visas ğimenes dzīves kvalitāti un līdzdalību sabiedrībā (Johnson, 2002; Pousada et al., 2013). Savukārt, bērna tuvinieku psihiskā, emocionālā un finansiālā labklājība it ļoti nozīmīgs bērna attīstību veicinošs faktors (Murphy et al., 2011; Rosenbaum, 2011). Tādēḷ veselības aprūpes pakalpojumu sniedzējiem būtu jāapzinās, ka sekmīgai bērna attīstībai nepieciešams tāds pakalpojumu veids, kas vienlaicīgi ir vērsts gan uz bērna, gan viņa ǵimenes funkcionēšanas uzlabošanu.

Pakalpojumi, kas tiek sniegti ievērojot uz gimeni vērstu pakalpojumu sniegšanas principus (family-centred services), ir atzīti par visefektīvākiem darbā ar ǵimenēm, kurās aug bērns ar attīstības traucējumiem (King et al., 2004; Kuhlthau et al., 2011). Tiek atzīmēts, ka šādā veidā iespējams sasniegt labākus rezultātus bērna funkcionēšanas uzlabošanā un ǵimenes specifisko vajadzību apmierināšanā, kā arī dzīves kvalitātes paaugstināšanā (Kuhlthau et al., 2011; Law et al., 2003; Dempsey \& Keen, 2008; Dunst \& Trivette, 2009; Darrah et al., 2012; Kuo et al., 2011; Almasri et al., 2011; Almasri et al., 2014). Par "uz g̊imeni vērstu pakalpojumu" uzskata tādu pakalpojumu formu, kur tiek uzklausīts un cienīts bērna tuvinieku viedoklis, ǵimenes tiek iesaistītas lēmumu pieņemšanā un bērna ārstniecībā vai rehabilitācijā, un nepieciešamais atbalsts tiek nodrošināts ikvienam ǵimenes pārstāvim (Rosenbaum, 2011). Tomēr veselības aprūpes speciālistiem pakalpojumu sniegšana, ievērojot uz ǵimeni vērstu pakalpojumu sniegšanas principus, ir izaicinājums (Espe-Sherwindt, 2008; Jeglinsky et al., 2012). Veselības aprūpes speciālisti atzīst, ka nav pietiekami kompetenti, lai spētu risināt jautājumus, kas nav tieši saistīti ar bērna medicīnisko stāvokli, kā arī atzīmēe, ka ne vienmēr ir informēti par gimenes vēlmēm un vajadzībām (Jeglinsky et al., 2012). 
Uz ǵimeni vērstu veselības aprūpes pakalpojumu būtisks aspekts ir ǵimenes vajadzību un prioritāšu apzināšana. (Bamm \& Rosenbaum, 2008; Dunst \& Dempsey, 2007). Savukārt zināšanas par gimenes vajadzības ietekmējošiem faktoriem palīdzētu izprast katras individuālās ǵimenes potenciālās vajadzības, tādējādi piedāvājot tieši to atbalstu, kas gimenei ir vissvarīgākais.

Pamatojoties uz gimenes sistēmas un cilvēka attīstības ekoloǵisko teoriju, potenciālos gimenes vajadzību ietekmējošos faktorus veido gan katra ǵimenes indivīda, gan ǵimenes kopējās, gan apkārtējās vides īpašības un raksturlielumi (Broderick, 1993). Tādēḷ zināšanas par bērna, ǵimenes un pakalpojumu raksturlielumiem, kas ir iespējamie gimenes vajadzību ietekmējošie faktori, veicinātu uz ġimeni vērstu pakalpojumu sniegšanu ǵimenēm, kurās aug bērns ar cerebrālo trieku, tādējādi sniedzot iespējami labāko atbalstu gan bērna attīstībai, gan gimenes dzīves kvalitātes uzlabošanā.

\section{Promocijas darba mērḳis}

Izpētīt un aprakstīt pirmsskolas vecuma bērnu ar cerebrālo trieku ǵimeņu vajadzības un izpētìt to saistîbu ar ġimeni, bērnu un rehabilitācijas pakalpojumus raksturojošiem faktoriem.

\section{Promocijas darba uzdevumi}

1. Noskaidrot pirmsskolas vecuma bērnu ar cerebrālo trieku gimeņu specifiskās vajadzības.

2. Izvērtēt un izanalizēt saistību starp bērnu ar cerebrālo trieku gimeņu vajadzībām un: 
- gimenes demogrāfisko un sociālekonomisko situāciju raksturojošiem faktoriem,

- bērnu ar cerebrālo trieku raksturojošiem faktoriem,

- rehabilitācijas pakalpojumu pieejamību, gimenes un rehabilitācijas pakalpojumu sniedzēju sadarbību raksturojošiem faktoriem.

3. Izvērtēt ǵimeni, bērnu un rehabilitācijas pakalpojumus raksturojošo faktoru ietekmi uz pirmsskolas vecuma bērnu ar cerebrālo trieku ǵimenes vajadzībām.

\section{Promocijas darba hipotēze}

Latvijā dzīvojošo pirmsskolas vecuma bērnu ar cerebrālo trieku gimen̦u vajadzības ietekmē ǵimeni, bērnu ar cerebrālo trieku un rehabilitācijas pakalpojumu sniedzējus raksturojoši faktori un šo faktoru unikālā ietekme ir atkarīga no gimenes vajadzību veida.

\section{Darba zinātniskā novitāte}

Bērnu ar cerebrālo trieku gimeņu vajadzību izpēte Latvijā tika veikta pirmo reizi. Pētījums atklāj Latvijā dzīvojošo pirmsskolas vecuma bērnu ǵimeņu specifiskās vajadzības, kā arī pētījuma ietvaros realizēta visaptveroša un sistemātiska pieeja, lai izprastu un identificētu gimeņu vajadzības ietekmējošos faktorus. Pētījumā iegūtie rezultāti ḷauj izprast ǵimenes specifisko vajadzību modeḷus un to ietekmējošos faktorus, tādējādi sekmējot veselības aprūpes pakalpojumu sniedzēju izpratni par potenciālajām pirmsskolas vecuma bērnu ar cerebrālo trieku gimenes vajadzībām, kā arī to ietekmējošiem faktoriem. 
Pêtījumā iegūtā informācija palīdzēs veselības aprūpes speciālistiem izvērtēt, izprast un prognozēt ǵimenes specifiskās vajadzības, ļaujot izstrādāt un realizēt uz gimenes vajadzībām balstītu pakalpojumu plānu, tādējādi uzlabojot sniegtā pakalpojuma kvalitāti un sekmējot bērna ar cerebrālo trieku ǵimenes dzīves kvalitāti un pilnvērtīgu iekḷaušanos sabiedrībā. 


\section{MATERIĀLS UN METODES}

\subsection{Bērnu ar cerebrālo trieku ğimeṇu vajadzības ietekmējošo faktoru konceptuālais modelis}

Ģimenes vajadzības ietekmējošo faktoru konceptuālais modelis

(1.1. attēls) tika izveidots pamatojoties uz:

- gimenes sistēmas un cilvēka attīstības ekologisko teoriju, kas nosaka, ka gimenes vajadzības var ietekmēt indivīda, ǵimenes kopējās, kā arī apkārtējās vides īpatnības (Broderick, 1993);

- visaptverošu literatūras izpēti, kurā tika apzināti bērnu ar cerebrālo trieku ǵimeņu vajadzību veidi un identificēti iespējamie ǵimenes vajadzības ietekmējošie faktori.

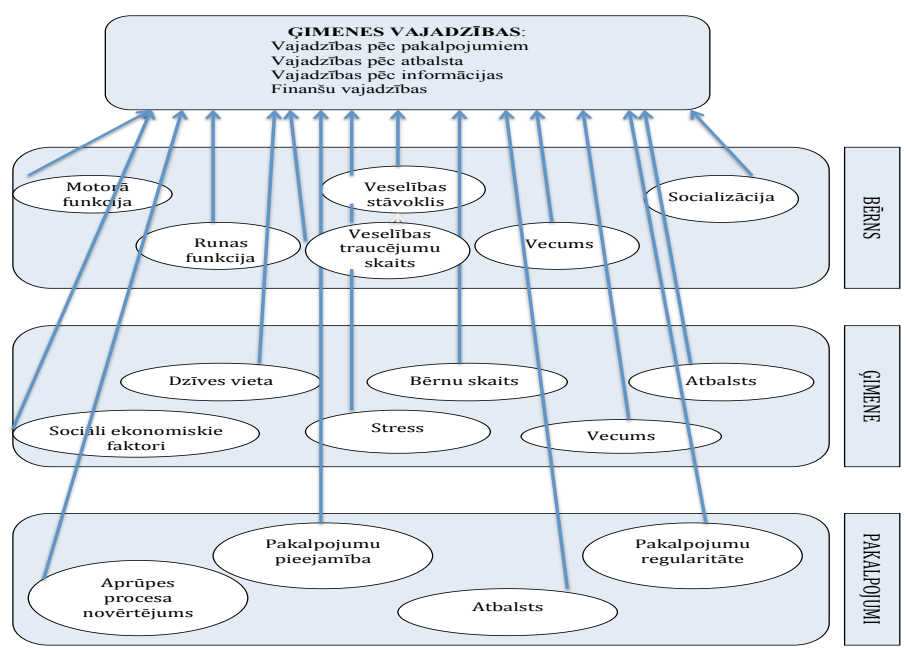

1.1. attēls. Ģimenes vajadzības ietekmējošo faktoru konceptuālais modelis 


\subsection{Pētījuma dalībnieki}

Pētījumā tika iekḷautas 234 Latvijā dzīvojošas gimenes, kuru aprūpē pētījuma datu ieguves periodā no 2012.gada 1.marta līdz 2013. gada 1.jūnijam bija bērns ar cerebrālās triekas diagnozi, un atbilda pētījuma iekḷaušanas kritērijiem:

Pētījuma iekḷaušanas kritēriji:

- bērna klīniskā pamatdiagnoze: cerebrālā trieka (pēc SSK-10 klasifikatora: G80) (SSK-10);

- bērna vecums no 2 līdz 7 gadiem (dzimis laika periodā no 2004. līdz 2010. gadam);

- $\quad$ gimene patstāvīgi dzīvo Latvijas Republikas teritorijā;

- bērna primārais aprūpētājs piekrīt piedalīties pētījumā.

Pētījumā netika iekḷautas gimenes gadījumā, ja varēja piemērot kādu no izslēgšanas kritērijiem:

- bērna primārā klīniskā diagnoze ir cita neiromuskulāra saslimšana;

- bērnam ar cerebrālo trieku ir papildus saslimšanas, kas varētu būtiski ietekmēt bērna un ǵimenes dzīves kvalitāti (piem., smagi autiska spektra traucējumi, cistiskā fibroze, l̦aundabīgs audzējs);

- kādam no gimenes locekḷiem ir smagi veselības traucējumi, kas var ietekmēt bērna un ǵimenes dzīves kvalitāti (piem., progresējoša neiromuskulāra saslimšana, smagi autiska spektra traucējumi, cistiskā fibroze, l̦aundabīgs audzējs, dziḷa garīga atpalicība);

- pēdējo divu gadu laikā ǵimene nav izmantojusi valsts vai pašvaldības institūciju pakalpojumus (piem., medicīnisko vai sociālo rehabilitāciju, pirmsskolas izglītīibas iestādi, dienas aprūpes centru) bērnam ar cerebrālo trieku. 


\subsection{Pētījuma procedūra}

Pētījuma autoru nolūks bija uzrunāt visas Latvijas Republikā dzīvojošās gimenes, kuru aprūpē ir pirmsskolas vecuma bērns ar cerebrālās triekas diagnozi vecumā no diviem līdz septiniiem gadiem. Informācija par Latvijā registrēto bērnu ar cerebrālo trieku skaitu tika iegūta balstoties uz Veselības un darbspēju ekspertīzes ārstu valsts komisijas (VDEĀK) datiem. Pēc VDEĀK sniegtās informācijas, Latvijā reǵistrēti 264 bērni, kuriem invaliditāte pieškirta pamatojoties uz SSK G80 kodu (cerebrālā trieka) un kuri dzimuši laika periodā no 2004. līdz 2010.gadam. Ģimeņu kontaktinformācija tika iegūta, izmantojot VSIA "Bērnu Klīniskā universitātes slimnīca", VSIA "Nacionālais rehabilitācijas centrs "Vaivari" un biedrības "Mēs esam līdzās" pacientu reǵistra datus un medicīnisko dokumentāciju. Ja dalībnieku atlases periodā ǵimene atradās kādā no minētajām ārstniecības iestādēm, tā tika uzrunāta. Ja giimene atbilda pētījuma iekḷaušanas kritērijiem un piekrita dalībai, tika veikts bērna funkcionēšanas izvērtējums, kā arī bērna primārais aprūpētājs aizpildīja novērtēšanas metodēs iekḷautās anketas. Ja gimene ārstniecības iestādē neatradās, tā tika uzrunāta telefoniski, lai informētu par pētījumu, un piekrišanas gadījumā, vienotos par tikšanās laiku. Vairumā gadījumu, tika izvēlēts periods, kad bērnam bija ieplānots kārtējais rehabilitācijas kurss kādā no minētajām ārstniecības iestādēm. Septiņas gimenes tika apmeklētas viṇu dzīves vietās.

Dalībnieku atlase un novērtēšana notika laika periodā no 2012. gada 1. marta līdz 2013. gada 1. jūnijam. Bērna funkcionēšanas izvērtēšana un anketu aizpildīšana aizṇēma vidēji 90 minūtes. Pētījuma autore bija klāt, lai atbildētu uz jautājumiem, kas varētu rasties anketu aizpildīšanas laikā. Daļa respondentu izvēejēās anketas aizpildīt ilgākā laika periodā un atgrieza tās nākamajā dienā. 
Iegūtie dati tika apkopoti un apstrādāti, izmantojot pētījuma datu statistiskās apstrādes un analīzes metodes.

Pētījums tika veikts, ievērojot ētikas principus saskaņā ar Helsinku deklarāciju un Latvijas likumdošanas aktu prasībām attiecībā uz personas datu aizsardzību. Pētījuma veikšanai ir pozitīvs Rīgas Stradiṇa universitātes Ētikas komitejas lēmums.

Tā kā pētījumā kā novērtēšanas metodes tika izmantotas standartizētas pašvērtējuma anketas, kuru oriğināli ir angḷu valodā un kuras latviešu valodā līdz šim nav tulkotas, tad pirms pētījuma anketas tika tulkotas atbilstoši Pasaules Veselības organizācijas rekomendācijām (WHO, Process of translation and adaptation of instruments) un veikts pilotpētījums, lai pārbaudītu anketu tulkojuma latviešu valodā ticamību. Pilotpētījumā pēc nejaušības principa tika iesaistīiti 20 vecāki, kuri darbojās biedrībā "Biedrība Latvijas Bērniem ar Kustību Traucējumiem" un kuriem bija pirmsskolas vecuma bērni ar neprogresējošām neiroloǵiskām saslimšanām. Vecāki divas reizes (ar 7 līdz 14 dienu intervālu) aizpildīja latviešu valodā tulkotās anketas. Lai novērtētu anketu latviešu valodas ticamību, tika veikts skalas iekšējās saskaņotības izvērtējums (Cronbach alpha analīze) un noteikta testa - atkārtotā testa veikšanas ticamība (Intraclass Correlation Coefficient).

\subsection{Novērtēšanas metodes}

\subsubsection{Aptaujas anketas}

Ģimenes vajadzību aptauja (The Family Needs Survey)

Lai identificētu gimenes vajadzības, bērna primārais aprūpētājs aizpildīja "Ģimenes vajadzību aptauju" - modificētu Beilija un Simeonsona izveidoto The Family Needs Survey. Skala ir izveidota, lai apzinātu to gimeñu 
vajadzības, kuras audzina pirmsskolas vecuma bērnu ar attīstības traucējumiem (Bailey \& Simeonsson, 1988). The Family Needs Survey ir atbilstoši ticamības rādītāji. Iekšējā saskaņotība (Cronbach alpha) skalas blokos jeb vajadzību jomās ir robežās no $0,65-0,86$ (Sexton, 1995), testa - atkārtotā testa ticamība anketu aizpildot ar sešu mēnešu intervālu ir $r=0,81$, ja respondents ir bērna tēvs un $r=0,67$, ja respondents ir bērna māte (Bailey \& Simeonsson, 1988).

Oriǵinālajā anketā ir 35 apgalvojumi, identificêjot gímenes vajadzības sešās vajadzību jomās: 1) vajadzība pēc informācija; 2) vajadzība pēc atbalsta; 3) izskaidrošana citiem; 4)vajadzība pēc pakalpojumiem; 5) finanšu vajadzības; 6) ǵimenes funkcionēšanas vajadzības. Lai varētu apzināt arī to gimeṇu vajadzības, kuru bērni vairs nav pirmsskolas vecumā, Palisano ar kolēgiem aptauju papildināja ar vairākiem apgalvojumiem (Palisano et al., 2010).

Ar autoru aţ̦auju, šajā pētījumā tika izmantota oriǵinālā anketa, kas papildināta ar trim Palisano un kolẹgu ieteiktiem jautājumiem un pievienojot trīs apgalvojumus, kas l̦autu identificēt vajadzības saistītas ar pakalpojumu pieejamību un koordināciju. Kā rezultātā oriǵinālā aptaujas versija tika papildināta ar sekojošiem apgalvojumiem:

- Man nepieciešama papildu informācija, lai plānotu mana bērna labklājību nākotnē (aizbildniecība, apdrošināšana, nodarbošanās u.c.).

- Man nepieciešama papildu informācija par mana bērna izglīīības iespējām.

- Man nepieciešama palīdzība, lai izskaidrotu mana bērna stāvokli skolotājiem un citiem profesionāḷiem.

- Man nepieciešama palīdzība, lai nodrošinātu bērnam nepieciešamos rehabilitācijas pakalpojumus.

- Man nepieciešama palīdzība, lai koordinētu medicīniskos, sociālos, izglītības pakalpojumus, ko piedāvā valsts vai pašvaldība. 
- Man nepieciešama papildu palīdzība, lai veiktu mājokḷa pārbūvi bērna vajadzībām.

Lai pārbaudītu latviešu valodā tulkotās un papildinātās anketas ticamību, tika veikts pilotpētījums. Pilotpētījumā The Family Needs Survey anketas latviešu valodas tulkojumam bija laba iekšējā saskaņotība (Cronbach alpha $0,82)$ un augsta testa - atkārtotā testa ticamība $(I C C=0,89)$ (Bērtule \& Vētra, 2012).

Iekšējās saskaņotības un testa - atkārtotā testa ticamības rādītāji pa atsevišķiem aptaujas blokiem (vajadzību jomas) atspoguḷoti 1.1. tabulā.

1.1. tabula

“Ģimenes vajadzību aptaujas" latviešu valodas tulkojuma iekšējās saskaṇotības un testa - atkārtotā testa rādītāji

\begin{tabular}{|l|c|c|}
\hline \multicolumn{1}{|c|}{ Vajadzību jomas } & Cronbach alpha & ICC \\
\hline Vajadzība pēc informācijas & 0,78 & 0,72 \\
\hline Vajadzība pēc atbalsta & 0,71 & 0,91 \\
\hline Izskaidrošana citiem & 0,74 & 0,94 \\
\hline Vajadzība pēc pakalpojumiem & 0,78 & 0,88 \\
\hline Finanšu vajadzības & 0,89 & 0,98 \\
\hline Ģimenes funkcionēšana & 0,85 & 0,97 \\
\hline
\end{tabular}

Atbildot uz katru anketas apgalvojumu, respondentam jāatzīmē viens no piedāvātajiem atbilžu variantiem: "1" (Nē); "2" (Neesmu pārliecināts); "3" (Jā).

Tā kā atbildes "1" un "2" neliecina par pārliecinošu vajadzību, tad šajā pētījumā, lai identificētu ğimeņu vajadzību veidu un skaitu, tās netika ņemtas vērā. Ģimenes kopējo vajadzību skaita noteikšanai tika saskaitîts cik reižu atzīmēta atbilde "3" (JĀ). Tāds pats princips tika ievērots aprēķinot vajadzību skaitu atsevišķās vajadzību jomās. Tā kā divas no izdalītajām vajadzību jomām (vajadzība pēc atbalsta un gimenes funkcionēšana) ir saistītas ar vēlmi pēc 
atbalsta, tad līdzīgi kā Almasri pētījumā, tās tika apskatītas kā vienots vajadzību bloks - vajadzība pēc atbalsta (Almasri, O’Neil \& Palisano, 2014).

\section{Aptaujas anketa vispārējās informācijas iegūšanai}

Pētījuma autori izveidoja anketu, lai iegūtu informāciju par bērna primārā aprūpētāja vecumu un izglîtību, ǵimenes struktūru, sociālekonomisko stāvokli, dzīves vietu un bērna vispārējo veselības stāvokli, kā arī rehabilitācijas pakalpojumu pieejamību dzīves vietā un rehabilitācijas saņemšanas kārtību.

Aprūpes procesa novērtējums: APN-20 (Measure of Processes of Care: MPOC-20)

"Aprūpes procesa novērtējums" ir vecāku vērtējums veselības aprūpes pakalpojumiem, un parāda to, cik lielā mērā saņemtais pakalpojums ir uz gimeni vērsts (family centred). APN-20 ir starptautiski plaši pielietots, standartizēts un validēts mērījums (King et al., 2004). Anketas 20 jautājumi sniedz vērtējumu veselības aprūpes pakalpojumu atbilstībai sekojošiem uz ǵimeni vērstu pakalpojumu principiem:

- Iedrošināšana un sadarbība.

- Vispārējās informācijas sniegšana.

- Specifiskas informācijas par bērnu sniegšana.

- Koordinēta un visaptveroša aprūpe.

- Cieņpilna un atbalstoša vide.

Pētījumā tika izmantota APN-20 anketas latviešu valodas versija. "Pilot" pētījumā anketas latviešu valodas tulkojumam bija augsta skalas iekšējā saskaņotība (Cronbach alpha $=0,87$ ) un testa - atkārtotā testa ticamība $(I C C=0,96)(B \bar{e} r t u l e ~ \&$ Vētra, 2012). 
Aizpildot anketu uz katru jautājumu, respondents sniedz atbildi, atzīmējot vienu no sekojošiem Likerta skalas vērtējumiem: 7 - l̦oti lielā mērā; 6 - lielā mērā; 5 - diezgan lielā mērā; 4 - vidēji; 3 - mazliet; 2 - l̦oti maz; 1 nemaz.

Datu analīzes nolūkos atzīmētās vērtības tika summētas katrā anketas sadaḷa atsevišḳi un dalītas ar sadạ̦ā ietilpstošo jautājumu skaitu, tādējādi iegūstot vērtējumu par katru no anketā apskatītajiem uz gimeni vērsta pakalpojuma principiem. Jo vērtība augstāka, jo veselības aprūpes pakalpojumi ir vairāk uz gimeni vērsti.

\section{Ģimenes atbalsta skala (Family Support Scale)}

Ģimenes atbalsta skala (G̣AS) tika izstrādāta, lai noskaidrotu, kas un cik lielā mērā sniedz atbalstu un palīdzību vecākiem, kuri aprūpē bērnu ar attīstības traucējumiem. Skalu veido 18 jautājumi, uz kuriem atbildot respondents sniedz vērtējumu par to, cik lielā mērā jautājumā minētā persona vai organizācija ir palīdzējusi vai sniegusi atbalstu. Jautājumi ir sagrupēti sniedzot kopējo informāciju par to, cik lielā mērā bērna primārais aprūpētājs saṇem atbalstu un palīdzību no:

- gimenes locekḷiem;

- draugiem;

- $\quad$ sociālajām grupām, piemēram, kolēgiem, vecāku atbalsta grupām;

- profesionāliem, piemēram, terapeita, psihologa.

Vērtējums tiek izteikts izmantojot Likerta skalu, iespējamie atbilžu varianti ir: 5 - ārkārtīgi palīdz; 4 - l̦oti palīdz; 3 - parasti palīdz; 2 - dažreiz palīdz; 1 - nemaz nepalīdz. Augstāks kopējais punktu skaits liecina par lielāku saņemto atbalstu un palīdzību. Ģimenes atbalsta skala ir standartizēta, tai ir 
klīniskai lietošanai atbilstoši ticamības un pamatotības rādītāji (Dunst, Jenkins \& Trivette, 1984).

Pētījumā tika izmantota skalas latviešu valodas versija. Pirms pētījuma veiktajā pilotpētījumā ĢAS latviešu valodas tulkojumam bija adekvāta skalas iekšejāas saskaņotība (Cronbach alpha $=0,81)$ un testa - atkārtotā testa ticamība $(I C C=0,91)$. Šajā pētījumā atspoguḷojot atbalstu, ko saņem bērna primārais aprūpētājs, izdalījām trīs saṇemtā atbalsta veidus:

- gimenes atbalsts;

- neformālais atbalsts (apvienojot draugu un sociālo grupu sniegto atbalstu);

- profesionālais atbalsts.

\section{Uztvertā stresa skala-10 (Perceived Stress Scale-10)}

Uztvertā stresa skala (USS) mēra cik lielā mērā indivīds pēdējā mēneša laikā ir izjutis situācijas, kuras varētu izraisīt stresu. Skala ietver 10 gan pozitīvi, gan negatīvi vērstus apgalvojumus uz kuriem respondentam jāsniedz atbilde pēc Likerta skalas principa. Atbilžu varianti ir: 5 - ļoti bieži; 4 diezgan bieži; 3 - dažreiz; 2 - gandrīz nekad; 1 - nekad. Lai iegūtu kopējo uztvertā stresa rādītāju, pozitīvi vērstiem apgalvojumi tiek piešķirts apgriezts punktu skaits (t.i., ja ir atzīmēts punkts "5", tas tiek pārvērsts par punktu "1" utml.), tad visu apgalvojumu punkti tiek saskaitīti un iegūts kopējais uztvertā stresa rādītājs. Jo šis rādītājs lielāks, jo personai ir augstāks uztvertā stresa līmenis.

Uztvertā stresa skala plaši tiek pielietota psihologijas, socioloǵijas un veselības aprūpes pētījumos, skala ir standartizēta un pārbaudīta tās ticamība un pamatotība lietošanai dažāda vecuma indivīdiem (Cohen, Kamarck \& Mermelstein, 1983).

Pētījumā, ar Latvijas Universitātes Psihologijas nodaḷas un autores ațauju, tika izmantota Ievas Stokenbergas promocijas darba "Humora loma 
stresa pārvarēšanas procesā" ietvaros tulkotā skalas latviešu valodas versija. Iekšējās saskaņotības rādītāji Uztvertā stresa skalas tulkojumam latviešu valodā bija Cronbach alpha $=0,83$ (Stokenberga, 2008).

\subsubsection{Bērna funkcionēšanas novērtēšana}

Lielo motoro funkciju klasifikācijas skala - LMFKS (The Gross Motor Function Classification Scale-GMFCS)

LMFKS ir piecu līmeṇu klasifikācijas sistēma, ko izmanto bērnu ar cerebrālo trieku kustību ierobežojumu raksturošanai. Skala ir standartizēta un klīniski aprobēta lietošanai motorās funkcijas raksturošanai bērniem no viena līdz 18 gadiem (Palisano et al., 1997). Motoro funkciju izvērtēšana un klasifikācija notiek atbilstoši bērna vecumam. Ir izstrādāts LMFKS kustību prasmju izvērtējuma apraksts piecām vecuma grupām: līdz 2 gadiem, 2-4 gadi, 4-6 gadi, 6-12 gadi, 12-18 gadi. Izvērtēšana notiek novērojot bērna sēdēšanas, pozu maiņas un pārvietošanās prasmes, un atbilstoši veikumam, tiek noteikts, kuram LMFKS līmenim bērna motorās funkcijas atbilst. Bērni, kuru motorās spējas atbilst LMFKS I līmenim, spēj veikt gandrīz tās pašas aktivitātes, ko viņu vienaudži, vienīgi veikšanas ātrums, līdzsvars vai koordinācija var atšķirties. Savukārt bērni, kuru motorās prasmes atbilst V līmenim, nespēj kontrolēt galvas un ķermeņa stāvokli, veikt mērkstiecīgas kustības un pārvietoties. LMFKS, kā bērna kustību spējas raksturojošs mērījums, plaši tiek lietots gan ikdienas klīniskajā darbā, gan pētniecībā, jo sniedz strukturētu informāciju par pētījuma dalībnieku kustību ierobežojuma līmeni (Rethlefsen et al., 2010). İss LMFKS līmeņu apraksts apkopots 1.2. tabulā. 
1.2. tabula

Lielo motoro funkciju klasifikācijas sistēmas (LMFKS) līmeṇu apraksts

\begin{tabular}{|c|l|}
\hline Līmenis & \multicolumn{1}{c|}{ Apraksts } \\
\hline I & Staigā bez ierobežojumiem \\
\hline II & Staigā ar ierobežojumiem \\
\hline III & Pārvietojas ar staigāšanas palīgierīci \\
\hline IV & $\begin{array}{l}\text { Patstāvīga pārvietošanās ir ierobežota - pārvietojas manuālajā } \\
\text { riteñkrēslā vai tiek pārvietots }\end{array}$ \\
\hline V & Patstāvīgas pārvietošanās nav - bērns tiek transportēts \\
\hline
\end{tabular}

Bērna motoro funkciju izvērtējums notika novērojot bērnu fizioterapijas nodarbības laikā terapijas zālē vai citās ēkas telpās (piemēram, lai izvērtētu pārvietošanos pa kāpnēm), neskaidrību gadījumos konsultējoties ar bērna fizioterapeitu un aprūpētāju. Gadījumā, ja gimene tika apmeklēta to dzīves vietā, novērtēšana tika veikta tajā.

\section{Komunikācijas funkciju klasifikācijas sistēma - KFKS (The Communication Function Classification System - CFCS)}

Hidekeres un kolēǵu izveidotā KFKS ir piecu līmeņu komunikācijas spēju raksturojoša klasifikācijas sistēma, kas sākotnēji tika izstrādāta tieši bērnu ar cerebrālo trieku populācijai (Hidecker et al., 2011), bet nesen apstiprināta tās lietojamība arī citos gadījumos, kad bērniem novērojami komunikācijas traucējumi (Hidecker et al., 2017). Skala ir izmantojama komunikācijas spēju raksturošanai bērniem no diviem gadiem. Prasmju klasifikācijas princips ir līdzīgs kā LMFKS - bērni, kuru komunikācija atbilst KFKS I līmenim ikdienā sazinās līdzịgi kā viṇu vienaudži, kuriem nav komunikācijas traucējumi. Savukārt bērni, kuru komunikācijas prasmes atbilst V KFKS līmenim, nespēj efektīvi komunicēt. Lai noteiktu, kuram KFKS līmenim bērna komunikācijas prasmes ir atbilstošas, tiek novērota bērna ikdienas komunikācija gan ar tuviniekiem, gan nepazīstamiem cilvēkiem. Tiek izvērtēta bērna prasmes uztvert informāciju un to nodot, neskatoties uz to kādā veidā tas tiek darīts. 
Saziņai bērns var izmantot valodu, acu skatu, žestus, komunikācijas palīgierīces utml. KFKS līmeņu apraksts apkopots 1.3. tabulā.

1.3. tabula

Komunikācijas funkciju klasifikācijas sistēmas līmeṇu apraksts

\begin{tabular}{|c|l|}
\hline Līmenis & \multicolumn{1}{|c|}{ Apraksts } \\
\hline I & $\begin{array}{l}\text { Efektīva informācijas apmaiņa ar pazīstamām un nepazīstamām } \\
\text { personām }\end{array}$ \\
\hline II & $\begin{array}{l}\text { Informācijas apmainaa ar paz̄istamām un nepazīstamām personām, bet } \\
\text { komunikācija notiek lēnāk }\end{array}$ \\
\hline III & Informācijas apmaiṇa tikai pazīstamām personām \\
\hline IV & Nekonsekventa informācijas apmaina pat ar paz̄istamām un personām \\
\hline V & Efektīva informācijas apmaiṇa pat ar paz̄̄stamām personām notiek reti \\
\hline
\end{tabular}

Komunikācijas prasmju izvērtējums notika bērnu novērojot terapiju laikā kontaktējoties ar fizioterapeitu, ergoterapeitu vai audiologopēdu un iesaistot sarunā ar pētījuma autori, kuru bērns nepazina. Tika novērots, kā notiek komunikācija ar kādu no tuviniekiem, kā arī uzklausīts aprūpētāju vērtējums bērna komunikācijas iemaņām. Atbilstošais KFKS līmenis uzreiz tika noteikts gadījumos, ja pētījuma autores un bērna aprūpētāju vērtējums sakrita. Ja viedokḷi atšḳīās, tad KFKS līmeņa precizēšanai tika iesaistīts audiologopēds vai logopēds, kurš bērnu pazina.

Pētìjuma analīzē izmantotie dati un to raksturojums apkopoti 1.4. tabulā.

1.4. tabula

Pētījuma analīzē izmantotie dati un to raksturojums

\begin{tabular}{|l|l|}
\hline \multicolumn{1}{|c|}{ Main̄̄gais } & \multicolumn{1}{c|}{ Datu ieguves avots, raksturojums } \\
\hline \multicolumn{2}{|c|}{ ATKARĪGIE MAINĪGIE } \\
\hline Gimenes vajadzības (kopā) & GVA: punktu skaits 0-41 \\
\hline Vajadzība pēc informācijas & GVA: punktu skaits 0-9 \\
\hline Vajadzība pēc atbalsta & GVA: punktu skaits 0-13 \\
\hline Finanšu vajadzības & GVVA: punktu skaits 0-7 \\
\hline Vajadzība pēc pakalpojumiem & GVA: punktu skaits 0-6 \\
\hline
\end{tabular}




\section{4. tabulas turpinājums}

\begin{tabular}{|c|c|}
\hline Mainīgais & Datu ieguves avots, raksturojums \\
\hline \multicolumn{2}{|c|}{ NEATKARĪGIE MAINĪGIE } \\
\hline \multicolumn{2}{|c|}{ Bērnu ar cerebrālo trieku raksturojošie faktori } \\
\hline Bērna vecums & Anketa; gadi \\
\hline Motorā funkcija & LMFKS: punktu skaits $1-5$ \\
\hline Komunikācijas funkcija & KFKS: punktu skaits $1-5$ \\
\hline Asociatīvās veselības problēmas (skaits) & Anketa: traucējumu skaits $0-6$ \\
\hline $\begin{array}{l}\text { Veselības stāvoklis (aprūpētāja } \\
\text { vērtējums) }\end{array}$ & Anketa: drīzāk labs/drīzāk slikts \\
\hline $\begin{array}{l}\text { Socializācija (apmeklē bērnu dārzu vai } \\
\text { dienas centru) }\end{array}$ & Anketa: jā/nē \\
\hline \multicolumn{2}{|c|}{ Ģimeni raksturojošie faktori } \\
\hline Respondenta vecums & Anketa: gadi \\
\hline Respondenta nodarbinātība & Anketa: strādā/nestrādā \\
\hline Respondenta izglìtíba & $\begin{array}{l}\text { Anketa: pamatizglītība/ vidējā izglìtība/ } \\
\text { augstākā izglīīîa }\end{array}$ \\
\hline Ģimenes stāvoklis & $\begin{array}{lll}\begin{array}{l}\text { Anketa: precējies } \\
\text { partneris/vientul̦s }\end{array} & \text { vai } & \text { ir } \\
\end{array}$ \\
\hline $\begin{array}{l}\text { Ģimenes ienākumu līmenis (respondenta } \\
\text { vērtējums) }\end{array}$ & Anketa: augsts / vidējs/ zems \\
\hline Bērnu skaits gimenē & Anketa: viens/ divi vai vairāk \\
\hline Dzīvesvieta & $\begin{array}{l}\text { Anketa: Rīga/ cita LV pilsēta/ lauku } \\
\text { teritorija }\end{array}$ \\
\hline Stressa līmenis & USS: punktu skaits $10-50$ \\
\hline G̦imenes atbalsts & GAS: punktu skaits 6-30 \\
\hline Neformālais atbalsts & ĢAS: punktu skaits $7-35$ \\
\hline \multicolumn{2}{|c|}{ Pakalpojumus raksturojošie faktori } \\
\hline Profesionālu atbalsts & GAS: punktu skaits 5-25 \\
\hline Rehabilitācijas pieejamība dzīves vietā & Anketa: jā/nē \\
\hline $\begin{array}{l}\text { Rehabilitācijas pakalpojumu saņemšanas } \\
\text { kārtība }\end{array}$ & $\begin{array}{l}\text { Anketa: regulāri/ kursu veidā divas vai } \\
\text { vairākas reizes gadā/ kursu veidā vienu } \\
\text { reizi gadā vai retāk }\end{array}$ \\
\hline \multicolumn{2}{|l|}{$\begin{array}{l}\text { Pakalpojumu atbilstība uz ǵimeni vērsta } \\
\text { pakalpojuma sniegšanas principiem: }\end{array}$} \\
\hline Iedrošināšana un sadarbība & APN-20: punktu skaits 3-21 \\
\hline Vispārējās informācijas sniegšana & APN-20: punktu skaits 5-35 \\
\hline $\begin{array}{l}\text { Specifiskas informācijas par bērnu } \\
\text { sniegšana }\end{array}$ & APN-20: punktu skaits 3-21 \\
\hline Koordinēta un visaptveroša aprūpe & APN-20: punktu skaits 4-28 \\
\hline Cieṇpilna un atbalstoša vide & APN-20: punktu skaits 5-35 \\
\hline
\end{tabular}




\subsection{Datu statistiskā analīze}

Datu analīzei tika izmantotas aprakstošās statistikas metodes (vidējie lielumi, standarta novirze, minimālie un maksimālie lielumi), kā arī veikta atsevišķu datu sastopamības biežuma analīze. Datu atbilstība normālajam sadalījumam tika pārbaudīta ar histogrammām.

Lai izpētītu dažādu faktoru ietekmes ticamību un izteiktību uz vienu modeli (ğimenes vajadzības), kas sastāv no vairākiem latentiem mainīgiem, tika pielietota daudzfaktoru lineārās regresijas analīze, veicot sekojošus soḷus:

- pārbaudīts vai atkarīgā pazīme un neatkarīgās kvantitatīvās pazīmes ir normāli sadalītas. Ja atkarīgā pazīme neatbilda normālajam sadalījumam, tika veikta tās logoritmiska pārveidošana;

- lai noteiktu vai starp atkarīgo un neatkarīgo mainīgo pastāv sakarība, atkarībā no analizējamo datu veida un atbilstības normālsadalījumam, tika veikta Pīrsona vai Spīrmena korelācijas analīze. Tikai tie neatkarīgie mainīgie, kuri statistiski ticami $(\mathrm{p}<0,05)$ korelēja ar atkarīgo main̄̄go tika iekḷauti regresijas analīzē;

- ja neatkarīgā pazīme bija nomināla ar vairākām kategorijām, tā tika pārveidota aizvietotājmainīgajos (dummy variables);

- tika veikta daudzfaktoru lineārās regresijas analīze, modelī iekḷaujot atlasītos neatkarīgos mainīgos. Regresijas analīzei tikai izmantota metode Enter, taču rezultātu salīdzināšanai tika pielietotas arī Forward un Backward metodes;

- labākais modelis tika izvēlēts salīdzinot tos izmantojot $F$ testu. Ja divi modeļi būtiski atšşīīās $(p<0,05)$, tika izvēelēts modelis ar augstāku $\mathrm{R}^{2}$ vērtību. Savukārt, ja modeḷi būtiski neatšķīrās, tad tika izvēlēts modelis ar mazāku izskaidrojošo faktoru skaitu;

- katram gala modelim, kas vislabāk izskaidroja iznākumu, tika pārbaudīts 
vai tiek izpildīti kolinearitātes, linearitātes un normālsadalījuma nosacījumi;

- faktori, kas tika iekḷauti gala modelī un bija statistiski nozīmīgi, pa kārtai tika izṇemti no modeḷa, un iegūtās $\mathrm{R}^{2}$ izmaiņas tika izmantotas katra faktora individuālās ietekmes aprakstīšanai.

Datu apstrāde tika veikta, izmantojot datorprogrammu IBM SPSS 17. versiju. 


\section{REZULTĀTI}

\subsection{Pētāmās grupas raksturojums}

NRC "Vaivari", BKUS un RC "Mēs esam līdzās" arhīvos un datu bāzēs tika identificēti 259 bērni vecumā no diviem līdz septiņiem gadiem ar slimības diagnozi G80. Ar piecu bērnu gimenēm neizdevās sazināties, 18 ǵimeņu pārstāvji atteicās piedalīties, divos gadījumos varēja piemērot kādu no izslēgšanas kritērijiem, tādēḷ pētījumā tika iesaistītas 234 ǵimenes: 236 bērni ar cerebrālās triekas diagnozi un 234 bērna primārie aprūpētāji.

Ģimenes pārstāvēja un aptaujas anketas aizpildīja galvenokārt bērna māte $(93,2 \%)$. Respondentu vidējais vecums bija 35,0 gadi ( $\mathrm{SN}=8,0$ gadi). Lielāka daļa $(82,1 \%)$ respondentu bija precējušies vai dzīvoja kopā ar pastāvīgu partneri. Puse no respondentiem datu ieguves periodā nestrādāja. Detalizēts respondentu un gimenes raksturojums atspoguḷots 2.1. tabulā.

2.1. tabula

Pētījumā iekḷauto personu un ğimeņu raksturojums saistībā ar pētītajiem faktoriem

\begin{tabular}{|l|c|c|c|}
\hline Raksturlielums & Skaits & $\overline{\text { İpatsvars \% }}$ & $\begin{array}{c}95 \% \text { ticamības } \\
\text { intervāls proporcijai }\end{array}$ \\
\hline Radniecība ar bērnu & 218 & 93,2 & $89,9-96,4$ \\
\hline Māte & 4 & 1,7 & $0,5-3,3$ \\
\hline Tēvs & 8 & 3,4 & $1,1-5,7$ \\
\hline Vecāmāte & 4 & 1,7 & $0,5-3,3$ \\
\hline Aizbildnis \\
\hline Respondenta izglītība \\
\hline Augstākā \\
\hline Vidusskolas/ koledžas & 122 & 39,3 & $33-45,6$ \\
\hline Pamatskolas & 20 & 82,2 & $45,6-58,6$ \\
\hline Nodarbin̄ātība & 117 & 50 & $4,9-12,1$ \\
\hline Strādā & 117 & 50 & $43,6-56,5$ \\
\hline Nestrādā &
\end{tabular}


2.1. tabulas turpinājums

\begin{tabular}{|c|c|c|c|}
\hline Raksturlielums & Skaits & İpatsvars \% & $\begin{array}{l}\text { 95\% ticamības } \\
\text { intervāls proporcijai }\end{array}$ \\
\hline \multicolumn{4}{|l|}{ Gimenes stāvoklis } \\
\hline Precējies / ir partneris & 192 & 82,1 & $77,1-87$ \\
\hline $\begin{array}{l}\text { Atraitnis /šķ̄īies/ vientuļais } \\
\text { vecāks }\end{array}$ & 42 & 17,9 & $13-22,9$ \\
\hline \multicolumn{4}{|l|}{ Bērnu skaits ǵimenē } \\
\hline Viens & 115 & 49,1 & $42,7-55,6$ \\
\hline Divi un vairāk & 119 & 50,9 & $44,8-56,1$ \\
\hline \multicolumn{4}{|l|}{ G̦imenes dzīvesvieta } \\
\hline Rīga & 84 & 35,9 & $29,7-42,1$ \\
\hline Cita Latvijas pilsēta & 89 & 38,0 & $31,7-44,3$ \\
\hline Latvijas lauku teritorija & 61 & 26,1 & $20,4-31,7$ \\
\hline \multicolumn{4}{|c|}{ Ģimenes vidējie ienākumi (EUR mēnesī) } \\
\hline mazāk nekā 420 & 42 & 18.0 & $13,9-23,9$ \\
\hline $420-839$ & 136 & 58.1 & $49,2-63,1$ \\
\hline $840-1120$ & 39 & 16,6 & $10,1-21,9$ \\
\hline vairāk nekā 1120 & 17 & 7.3 & $3,9-12,7$ \\
\hline \multicolumn{4}{|l|}{ G̦imenes ienākumu līmenis* } \\
\hline Zems & 44 & 18,8 & $14,1-24,2$ \\
\hline Vidējs & 157 & 67,1 & $61,1-73$ \\
\hline Augsts & 33 & 14,1 & $9,6-18,6$ \\
\hline
\end{tabular}

* Respondentu vērtējums

Respondentu uztvertā stresa (USS) rādītāji variēja no 6 līdz 42 punktiem, vidēji 24,4 punkti ( $\mathrm{SN}=7,1$ punkti).

Apkopojot respondentu vērtējumu atbalstam, ko ikdienā sniedz citi ǵimenes locekḷi (ĢAS ǵimene) tika konstatēts, ka tas ir robežās no 5 līdz 22 punktiem, vidēji 12,5 punkti ( $\mathrm{SN}=3,5$ punkti), savukārt draugu un sociālo grupu atbalsta vērtējums (ĢAS neformālais) variēja no 8 līdz 26 punktiem, vidēji 18,8 punkti ( $\mathrm{SN}=3,5$ punkti). Aptaujāto vērtējums medicīnas profesionāḷ sniegtajam atbalstam (ĢAS profesionāļi) bija robežās no 4 līdz 15 punktiem, vidēji 8,8 punkti ( $\mathrm{SN}=2,5$ punkti).

Vidējais vecums bērniem ar cerebrālo trieku bija 4,8 gadi $(\mathrm{SN}=1,7)$. Lielākajai daḷai $(79,9 \%)$ bērnu bija spastiskā cerebrālās triekas forma.

Papildus kustību traucējumiem 78,6 \% bērnu novēroja vēl vismaz vienu 
asociētu veselības traucējumu. Bērniem konstatēto asociēto veselības traucējumu kopējais skaits bija robežās no 0 līdz 5, vidēji $2,5(\mathrm{SN}=1,4)$. Detalizēts bērnu ar cerebrālās triekas diagnozi raksturojums atspoguḷots 2.2. tabulā.

2.2. tabula

Pētījumā iekḷauto bērnu ar cerebrālās triekas diagnozi raksturojums

\begin{tabular}{|c|c|c|c|}
\hline Raksturlielums & Skaits & Īpatsvars \% & $\begin{array}{c}\text { 95\% ticamības } \\
\text { intervāls proporcijai }\end{array}$ \\
\hline \multicolumn{4}{|l|}{ Dzimums } \\
\hline Zēns & 131 & 55,6 & $49,1-61,9$ \\
\hline Meitene & 105 & 44,4 & $38-50,8$ \\
\hline \multicolumn{4}{|c|}{ Saistîtie (asociētie) veselības traucējumi* } \\
\hline Redzes traucējumi & 93 & 39,7 & $33,4-45,9$ \\
\hline Dzirdes traucējumi & 28 & 12,0 & $7,8-16,1$ \\
\hline Izziñas traucējumi & 158 & 67,5 & $61,5-73,5$ \\
\hline Uzvedības traucējumi & 24 & 9,7 & $6,8-12,2$ \\
\hline Epilepsija & 58 & 24,8 & $19,3-29,9$ \\
\hline \multicolumn{4}{|l|}{ Vispārējais veselības stāvoklis* } \\
\hline Drīzāk labs & 94 & 39,7 & $36,2-43,1$ \\
\hline Drīzāk slikts & 142 & 60,3 & $56,1-64,8$ \\
\hline \multicolumn{4}{|l|}{ Socializācija } \\
\hline Bērnudārzs/dienas centrs & 139 & 59,4 & $53,1-65,2$ \\
\hline Nav - dzīvo mājās & 95 & 40,6 & $36,2-44,3$ \\
\hline \multicolumn{4}{|l|}{ Cerebrālās triekas forma } \\
\hline Spastiska unilaterāla & 77 & 32,9 & $26,8-28,9$ \\
\hline Spastiska bilaterāla & 112 & 47 & $40,5-53,4$ \\
\hline Diskinētiska & 25 & 10,7 & $6,7-14,6$ \\
\hline Ataksija & 9 & 3,8 & $1,4-6,3$ \\
\hline Jaukta & 13 & 5,6 & $2,6-8,5$ \\
\hline \multicolumn{4}{|l|}{ LMFKS līmenis } \\
\hline I & 78 & 33,3 & $27,3-39,1$ \\
\hline II & 45 & 19,2 & $14,7-23,8$ \\
\hline III & 45 & 18,1 & $14,4-21,7$ \\
\hline IV & 49 & 20,9 & $16,7-25,1$ \\
\hline $\mathrm{V}$ & 20 & 8,5 & $5,1-11,9$ \\
\hline \multicolumn{4}{|l|}{ KFKS līmenis } \\
\hline I & 55 & 23,5 & $19,3-27,8$ \\
\hline II & 42 & 17,9 & $13,5-21,9$ \\
\hline III & 45 & 18,4 & $14,3-22,3$ \\
\hline IV & 56 & 23,9 & $19,4-28,4$ \\
\hline $\mathrm{V}$ & 38 & 16,2 & $12,4-20$ \\
\hline
\end{tabular}

* Respondentu sniegtais vērtējums 


\subsection{Rehabilitācijas pieejamības un pakalpojumu saņemšanas kārtības raksturojums}

149 jeb 63,7\% (95\% CI: 58,7-68,1) respondentu atzīmēja, ka rehabilitācijas pakalpojumi ir pieejami dzīvesvietā, savukārt 85 jeb 36,3\% (95\% CI: 32,1-39,8) norādīja, ka dzīvesvietas tuvumā bērna vajadzībām piemērotu rehabilitācijas pakalpojumu nav.

Analizējot rehabilitācijas regularitāti konstatējām, ka 60 bērni jeb 25,6\% (95\% CI: 20-31,2) valsts finansētu rehabilitāciju saņem regulāri, 93 bērniem jeb 39,7\% (95\% CI: 33,4-46,1) rehabilitācija tiek nodrošināta kursu veidā vairākas reizes gadā, bet 81 bērns jeb 34,6\% (95\% CI: 28,4-40,7) rehabilitācijas kursu iziet vienu reizi gadā vai retāk.

\subsection{Aprūpes procesa novērtējuma rezultāti}

Aprūpes proces novērtējuma (APN-20) rezultātu analīze atklāja, ka rehabilitācijas pakalpojumu sniedzēji daḷeji ievēro uz ǵimeni vērstu pakalpojumu sniegšanas principus. Respondenti pozitīvāk vērtēja tādu principu ievērošanu kā cieņpilna un atbalstoša vide (vidējā vērtība $=4,84 ; \mathrm{SN}=1,8$ ), sadarbība (vidējā vērtība $=4,65 ; \mathrm{SN}=1,29)$ un koordinēta aprūpe (vidējā vērtība $=4,62 ; \mathrm{SN}=1,17)$. Negatīvāk tika vērtēta ar informācijas nodrošināšanu saistīto principu ievērošana - specifiskas informācijas sniegšana (vidējā vērtība $=3,62 ; \mathrm{SN}=1,21$ ) un vispārējas informācijas sniegšana (vidējā vērtība $=3,32 ; \mathrm{SN}=1,20)$.

\section{4. Ģimenes vajadzību aptaujas rezultāti}

Analizējot Ģimenes vajadzību aptaujas kopējos rezultātus, konstatējām, ka ikviens respondents atzīmēja vismaz trīs apgalvojumus par nepieciešamo palīdzību. 
Vislielākais atzīmēto vajadzības skaits tika konstatēts ĢVA sadaļā "Vajadzība pēc informācijas". Šajā sadaḷā vismazāk (53,4\%) respondenti bija norādījuši, ka viniiem nepieciešama informācija par bērna attīstību un par to, kā spēlēties ar bērnu, bet visbiežāk $(88,9 \%)$ tika atzīmēta nepieciešamība pēc informācijas par pakalpojumiem, kas pašlaik ir pieejami.

ĢVA sadạ̦ā "Vajadzība pēc atbalsta", atbildot uz sadaḷas astoņiem apgalvojumiem, visbiežāk tika minēta vēlme lasīt aprakstus par gimenēm ar līdzīgām problēmām (72,2\%), savukārt tikai 19,2\% aptaujāto norādīja, ka viņiem būtu nepieciešams kāds ǵimenes loceklis ar kuru varētu runāt par savām problēmām.

ĢVA sadaḷā "Pakalpojumi" visvairāk - 72,6\% respondentu - atzīmēja vajadzību saņemt palīdzību valsts vai pašvaldības piedāvāto medicīnisko, sociālo un izglītîbas pakalpojumu koordinēšanā. Savukārt tikai trīs respondenti norādīja, ka būtu nepieciešama palīdzība, lai dievkalpojuma laikā nodrošinātu bērnam atbilstošu aprūpi.

ĢVA sadaḷā "Finanšu vajadzības" vairums aptaujāto atzīmēja, ka būtu nepieciešams finansiāls atbalsts bērna ārstēšanas izdevumu segšanai (76,9\%) un speciāla aprīkojuma iegādei (57,3\%). Savukārt tikai $10 \%$ aptaujāto norādīja, ka g̛imenei nepieciešama finansiālā palīdzība, lai iegādātos bērnam rotalllietas.

Tikai neliela daḷa aptaujāto atzīmēja vajadzības, kas saistītas ar ǵimenes funkcionēšanas uzlabošanu (ĢVA sadaļa "Ģimenes funkcionēšana") vai, ka būtu nepieciešama palīdzība bērna stāvokḷa izskaidrošanā citiem cilvēkiem (ĢVA sadaḷa "Izskaidrošana citiem"). Detalizēts "Ģimenes vajadzību aptaujas" rezultātu apkopojums attēlots 2.3. tabulā. 


\section{Ģimenes vajadzību aptaujas rezultāti}

\begin{tabular}{|c|c|c|}
\hline Apgalvojums & Skaits* & $\begin{array}{c}\text { Ipatsvars } \\
\%\end{array}$ \\
\hline \multicolumn{3}{|l|}{ Vajadzība pēc informācijas } \\
\hline Man nepieciešama informācija par to kā bērni aug un attīstās & 125 & 53,4 \\
\hline Man nepieciešama informācija par mana bērna stāvokli vai slimību & 157 & 67,1 \\
\hline Man nepieciešama informācija, kā runāt un spēlēties ar manu bērnu & 125 & 53,4 \\
\hline Man nepieciešama informācija, kā mācīt manu bērnu & 178 & 76,1 \\
\hline $\begin{array}{l}\text { Man nepieciešama informācija, kā risināt mana bērna uzvedības } \\
\text { problēmas }\end{array}$ & 143 & 61,1 \\
\hline $\begin{array}{l}\text { Man nepieciešama informācija par pakalpojumiem, kas pašlaik ir } \\
\text { pieejami manam bērnam }\end{array}$ & 208 & 88,9 \\
\hline $\begin{array}{l}\text { Man nepieciešama informācija par pakalpojumiem, kādus manam } \\
\text { bērnam vajadzētu saņemt nākotnē }\end{array}$ & 199 & 85,0 \\
\hline $\begin{array}{l}\text { Man nepieciešama informācija, lai plānotu mana bērna labklājīīu } \\
\text { nākotnē }\end{array}$ & 167 & 71,4 \\
\hline Man nepieciešama informācija par mana bērna izglìtīibas iespējām & 200 & 85,5 \\
\hline \multicolumn{3}{|l|}{ Vajadzība pēc atbalsta } \\
\hline $\begin{array}{l}\text { Man vajadzētu ǵimenes locekli, ar kuru es varētu vairāk runāt par } \\
\text { savām problēmām }\end{array}$ & 45 & 19,2 \\
\hline Man vajadzētu vairāk draugu, ar kuriem es varētu parunāties & 63 & 26,9 \\
\hline $\begin{array}{l}\text { Man nepieciešama iespēja biežāk satikt un aprunāties ar vecākiem, } \\
\text { kuriem arī ir bērns ar îpašăm vajadzībām }\end{array}$ & 137 & 58,5 \\
\hline $\begin{array}{l}\text { Man vajadzētu lasāmvielu par ǵimenēm, kurās ir līdzīgs bērns } \\
\text { manējam }\end{array}$ & 169 & 72,2 \\
\hline Mani nepieciešams vairāk laika sev & 149 & 63,7 \\
\hline $\begin{array}{l}\text { Man nepieciešams, lai mana bērna skolotājs vai terapeits atvēlētu } \\
\text { vairāk laika sarunām ar mani }\end{array}$ & 105 & 44,9 \\
\hline $\begin{array}{l}\text { Man nepieciešams biežāk tikties ar garīdznieku, kas palīdzētu man } \\
\text { risināt problēmas }\end{array}$ & 51 & 21,8 \\
\hline $\begin{array}{l}\text { Es vēlētos regulārāk tikties ar psihiatru, psihologu un sociālo } \\
\text { darbinieku un apspriest man svarīgus jautājumus }\end{array}$ & 105 & 44,9 \\
\hline \multicolumn{3}{|l|}{ Izskaidrošana citiem } \\
\hline $\begin{array}{l}\text { Man nepieciešama palīdzība, lai izskaidrotu (zinātu, kā izskaidrot) } \\
\text { bērna stāvokli maniem vai partnera/partneres vecākiem }\end{array}$ & 34 & 14,5 \\
\hline $\begin{array}{l}\text { Man nepieciešama palīdzība, lai izskaidrotu bērna stāvokli viņa } \\
\text { tēvam/mātei }\end{array}$ & 21 & 9,0 \\
\hline $\begin{array}{l}\text { Man nepieciešama palīdzība, lai izskaidrotu (zinātu, kā izskaidrot) } \\
\text { bērna stāvokli viṇa brāliem un māsām }\end{array}$ & 19 & 8,1 \\
\hline $\begin{array}{l}\text { Man nepieciešama palīdzība, lai izskaidrotu (zinātu, kā izskaidrot) } \\
\text { mana bērna stāvokli citiem bērniem }\end{array}$ & 78 & 33,3 \\
\hline $\begin{array}{l}\text { Man nepieciešama palīdzība, lai zinātu, kā atbildēt, kad kaimiņi, } \\
\text { draugi vai svešinieki uzdod jautājumus par manu bērnu }\end{array}$ & 79 & 33,8 \\
\hline
\end{tabular}


2.3.tabulas turpinājums

\begin{tabular}{|c|c|c|}
\hline Apgalvojums & Skaits* & $\begin{array}{c}\text { Ipatsvars } \\
\%\end{array}$ \\
\hline $\begin{array}{l}\text { Man nepieciešama palīdzība, lai izskaidrotu (zinātu, kā izskaidrot) } \\
\text { mana bērna stāvokli skolotājiem un citiem profesionāliem }\end{array}$ & 68 & 29,1 \\
\hline \multicolumn{3}{|l|}{ Vajadzība pēc pakalpojumiem } \\
\hline $\begin{array}{l}\text { Man nepieciešama palīdzība, lai atrastu manam bērnam piemērotu } \\
\text { pirmsskolas aprūpes iestādi vai dienas centru }\end{array}$ & 108 & 46,5 \\
\hline $\begin{array}{l}\text { Man nepieciešama palīdzība, lai atrastu auklīiti, kas vēlētos un spētu } \\
\text { rūpēties par manu bērnu }\end{array}$ & 74 & 31,6 \\
\hline $\begin{array}{l}\text { Man nepieciešama palīdzība, lai nodrošinātu atbilstošu aprūpi } \\
\text { manam bērnam dievkalpojuma laikā }\end{array}$ & 3 & 1,3 \\
\hline $\begin{array}{l}\text { Man nepieciešama palīdzība, lai atrastu ārstu, kas saprot mani un } \\
\text { mana bērna vajadzības }\end{array}$ & 80 & 34,2 \\
\hline $\begin{array}{l}\text { Man nepieciešama palīdzība, lai nodrošinātu bērnam nepieciešamos } \\
\text { rehabilitācijas pakalpojumus }\end{array}$ & 143 & 61,1 \\
\hline $\begin{array}{l}\text { Man nepieciešama palīdzība, lai koordinētu medicīniskos, sociālos, } \\
\text { izglîtīibas pakalpojumus, ko piedāvā valsts vai pašvaldība }\end{array}$ & 170 & 72,6 \\
\hline \multicolumn{3}{|l|}{ Finanšu vajadzības } \\
\hline $\begin{array}{l}\text { Man nepieciešams papildu finansējums, lai segtu izdevumus par } \\
\text { èdienu, mājokli, medicīnisko aprūpi, apgéerbu un transportu }\end{array}$ & 92 & 39,3 \\
\hline $\begin{array}{l}\text { Man nepieciešama papildu palīdzība, lai iegādātos speciālo } \\
\text { inventāru (ratus, krēslu, pārvietošanās ierīci...) manam bērnam }\end{array}$ & 134 & 57,3 \\
\hline $\begin{array}{l}\text { Man nepieciešama papildu palīdzība, lai segtu izdevumus par terapiju } \\
\text { un citām ar bērna aprūpi saistîtām vajadzībām }\end{array}$ & 180 & 76,9 \\
\hline $\begin{array}{l}\text { Man nepieciešama papildu palīdzība, lai apmaksātu auklītes } \\
\text { pakalpojumus }\end{array}$ & 82 & 35,0 \\
\hline $\begin{array}{l}\text { Man nepieciešama papildu palīdzība, lai veiktu mājokḷa pārbūvi } \\
\text { bērna vajadzībām }\end{array}$ & 68 & 29,1 \\
\hline $\begin{array}{l}\text { Man nepieciešam papildu palīdzība, lai iegādātos manam bērnam } \\
\text { nepieciešamās rotallietas }\end{array}$ & 24 & 10,3 \\
\hline Man vai manam partnerim nepieciešama palīdzība, lai atrastu darbu & 45 & 19,2 \\
\hline \multicolumn{3}{|l|}{ G̦imenes funkcionēšana } \\
\hline $\begin{array}{l}\text { Manam partnerim/partnerei ir nepieciešama palīdzība, lai saprastu un } \\
\text { pien̨emtu mūsu bērna stāvokli }\end{array}$ & 12 & 5,1 \\
\hline $\begin{array}{l}\text { Mūsu ǵimenei nepieciešama palīdzība problēmu apspriešanā un } \\
\text { risināšanā }\end{array}$ & 40 & 17,1 \\
\hline $\begin{array}{l}\text { Mūsu ǵimenei nepieciešama palīdzība, lai mācītos, kā vienam otru } \\
\text { grūtos brīžos atbalstīt }\end{array}$ & 61 & 26,1 \\
\hline $\begin{array}{l}\text { Mūsu ǵimenei nepieciešama palīdzība, lai izlemtu kurš veiks } \\
\text { maksājumus, rūpēsies par bērnu vai veiks citus ar gimenes dzīvi } \\
\text { saistîtas darbības }\end{array}$ & 3 & 1,3 \\
\hline $\begin{array}{l}\text { Mūsu gimenei nepieciešama palīdzība, lai plānotu un realizētu b } \\
\text { laika aktivitātes }\end{array}$ & 39 & 16,7 \\
\hline
\end{tabular}

* Respondentu skaits, kas bija atzīmējuši atbildi "3" - "Jā" 
Vidējais respondentu atzīmētais kopējais vajadzību skaits bija 17,1 $(\mathrm{SN}=7,1)$, variējot no 3 līdz 38. Respondentu atbilžu raksturojošās punktu vērtības atsevišşāa vajadzību jomās atspoguḷotas 2.4. tabulā.

2.4. tabula

Ģimenes vajadzību aptaujas rezultāti pa vajadzību jomām

\begin{tabular}{|l|c|c|c|c|c|}
\hline \multicolumn{1}{|c|}{ Vajadzību jomas } & $\begin{array}{c}\text { Apgalvojumu } \\
\text { skaits }\end{array}$ & $\begin{array}{c}\text { Minimālā } \\
\text { vērtība }\end{array}$ & $\begin{array}{c}\text { Maksimālā } \\
\text { vērtība }\end{array}$ & $\begin{array}{c}\text { Vidējāā } \\
\text { vērtība }\end{array}$ & SN \\
\hline $\begin{array}{l}\text { Vajadzība pēc } \\
\text { informācijas }\end{array}$ & 9 & 0 & 9 & 6,5 & 2,0 \\
\hline Vajadzība pēc atbalsta & 8 & 0 & 8 & 3,5 & 2,1 \\
\hline Izskaidrošana citiem & 6 & 0 & 6 & 1,3 & 1,5 \\
\hline $\begin{array}{l}\text { Vajadzība pēc } \\
\text { pakalpojumiem }\end{array}$ & 6 & 0 & 6 & 2,5 & 1,3 \\
\hline Finanšu vajadzības & 7 & 0 & 7 & 2,7 & 1,4 \\
\hline Ģimenes funkcionēšana & 5 & 0 & 5 & 0,7 & 0,9 \\
\hline
\end{tabular}

Turpmākai analīzei divas no vajadzību jomām ("Vajadzība pēc atbalsta" un "Ģimenes funkcionēšana") tika apskatītas kopā, veidojot "Vajadzība pēc atbalsta", kur vidējais vajadzību skaits bija 4,3 (SN=2,1), variējot no 0 līdz 10 .

Tā kā sadạ̧ā "Izskaidrošana citiem" atzīmēto vajadzību skaits bija mazs, tad ietekmējošie faktori šai vajadzību jomai netika skatīti.

\subsection{Korelāciju analīzes rezultāti}

Lai noteiktu vai starp atkarīgo mainīgo (gímenes vajadzības) un neatkarīgo mainīgo (ğimeni, bērnu un rehabilitācijas pakalpojumus raksturojoši faktori) pastāv saistība, atkarībā no analizējamo datu veida un atbilstīibas normālsadalījumam, tika veikta Pīrsona vai Spīrmena korelācijas analīze. 


\subsubsection{Bērnu ar cerebrālo trieku raksturojošo faktoru saistība ar ğimenes vajadzībām}

Netika atrastas sakarības starp gimenes vajadzībām un bērna vecumu. Pārējie pētījumā apskatītie bērnu ar cerebrālo trieku raksturojošie faktori bija saistīti ar vismaz vienu gimenes vajadzību veidu. Statistiski nozīmīgās korelācijas atspoguḷotas 2.5. tabulā.

2.5. tabula

Statistiski nozīmīgas korelācijas starp giimenes vajadzībām un bērnu ar cerebrālo trieku raksturojošiem faktoriem

\begin{tabular}{|l|c|c|c|c|c|}
\hline & $\begin{array}{c}\text { Vajadzība } \\
\text { pēc } \\
\text { informācijas }\end{array}$ & $\begin{array}{c}\text { Vajadzība } \\
\text { pēc atbalsta }\end{array}$ & $\begin{array}{c}\text { Vajadzība pēc } \\
\text { pakalpojumiem }\end{array}$ & $\begin{array}{c}\text { Finanšu } \\
\text { vajadzības }\end{array}$ & $\begin{array}{c}\text { Gimenes } \\
\text { kopējās } \\
\text { vajadzības }\end{array}$ \\
\hline $\begin{array}{l}\text { LMFKS } \\
\text { līmenis }\end{array}$ & $0,10^{*}$ & $0,17^{*}$ & 0,45 & 0,44 & 0,34 \\
\hline $\begin{array}{l}\text { KFKS } \\
\text { līmenis }\end{array}$ & 0,34 & 0,24 & 0,46 & 0,37 & 0,42 \\
\hline Socializācija & $0,16^{*}$ & 0,22 & 0,42 & 0,26 & 0,31 \\
\hline $\begin{array}{l}\text { Vispārējais } \\
\text { veselības } \\
\text { stāvoklis }\end{array}$ & $0,15^{*}$ & - & - & - & $0,19^{*}$ \\
\hline $\begin{array}{l}\text { Asociēto } \\
\text { veselības } \\
\text { traucējumu } \\
\text { skaits }\end{array}$ & 0,28 & 0,36 & 0,37 & 0,36 & 0,46 \\
\hline
\end{tabular}

$\mathrm{p}<0,001 ;{ }^{*} \mathrm{p}<0,05$

\subsection{2. Ģimeni raksturojošo faktoru saistība ar gimenes vajadzībām}

Rezultātu analīze atklāja, ka nepastāv statistiski nozīmīga saistība starp gimenes vajadzībām un bērna primārā aprūpētāja vecumu, kā arī gimenes stāvokli. Pārējie pētījumā apskatīitie gimeni raksturojošie faktori bija saistīti ar vismaz vienu gimenes vajadzību veidu. Statistiski nozīmīgās korelācijas atspoguḷotas 2.6. tabulā. 
2.6. tabula

Statistiski nozīmīgas korelācijas starp ğimenes vajadzībām un gimeni raksturojošiem faktoriem

\begin{tabular}{|c|c|c|c|c|c|}
\hline & $\begin{array}{c}\text { Vajadzība } \\
\text { pēc } \\
\text { informācijas } \\
\end{array}$ & $\begin{array}{c}\text { Vajadzība } \\
\text { pēc } \\
\text { atbalsta } \\
\end{array}$ & $\begin{array}{c}\text { Vajadzība pēc } \\
\text { pakalpojumiem }\end{array}$ & $\begin{array}{c}\text { Finanšu } \\
\text { vajadzības }\end{array}$ & $\begin{array}{c}\text { Ģimenes } \\
\text { kopējāā } \\
\text { vajadzības }\end{array}$ \\
\hline $\begin{array}{l}\text { Izglīitibas } \\
\text { lîmenis }\end{array}$ & $0,16^{*}$ & $0,19^{*}$ & - & - & $0,20^{*}$ \\
\hline Nodabinātība & 0,21 & $0,19^{*}$ & 0,33 & 0,35 & 0,34 \\
\hline $\begin{array}{l}\text { Ģimenes } \\
\text { ienākumu } \\
\text { līmenis }\end{array}$ & 0,31 & 0,29 & 0,36 & 0,46 & 0,43 \\
\hline $\begin{array}{l}\text { Ģimenes } \\
\text { dzīvesvieta }\end{array}$ & - & - & $0,19^{*}$ & - & - \\
\hline $\begin{array}{l}\text { Bērnu skaits } \\
\text { gimenē }\end{array}$ & - & - & - & $0,15^{*}$ & - \\
\hline $\begin{array}{l}\text { Stresa } \\
\text { lìmenis }\end{array}$ & 0,22 & 0,30 & $0,15^{*}$ & $0,22^{*}$ & 0,33 \\
\hline $\begin{array}{l}\text { Ģimenes } \\
\text { atbalsts }\end{array}$ & $-0,23$ & $-0,44$ & $-0,18^{*}$ & $-0,27$ & $-0,39$ \\
\hline $\begin{array}{l}\text { Neformālais } \\
\text { atbalsts }\end{array}$ & $-0,28$ & $-0,26$ & $-0,13^{*}$ & $-0,19 *$ & $-0,31$ \\
\hline
\end{tabular}

$\mathrm{p}<0,001 ; * \mathrm{p}<0,05$

\subsubsection{Rehabilitācijas pakalpojumus raksturojošo faktoru saistība ar gímenes vajadzībām}

Korelāciju analīzē tika konstatēts, ka visi pētījumā iekļautie rehabilitācijas pakalpojumus raksturojošie faktori bija nozīmīgi saistīti ar vismaz vienu gimenes vajadzību veidu. Statistiski nozīmīgās korelācijas atspoguļotas 2.7. tabulā. 


\section{Statistiski nozīmīgas korelācijas starp ǵimenes vajadzībām un rehabilitācijas pakalpojumus raksturojošiem faktoriem}

\begin{tabular}{|c|c|c|c|c|c|}
\hline & $\begin{array}{c}\text { Vajadzība } \\
\text { pēc } \\
\text { informācijas }\end{array}$ & $\begin{array}{c}\text { Vajadzība } \\
\text { pēc atbalsta }\end{array}$ & $\begin{array}{c}\text { Vajadzība } \\
\text { pēc } \\
\text { pakalpojumiem }\end{array}$ & $\begin{array}{c}\text { Finanšu } \\
\text { vajadzības }\end{array}$ & $\begin{array}{c}\text { Ģimenes } \\
\text { kopējās } \\
\text { vajadzības }\end{array}$ \\
\hline $\begin{array}{l}\text { Cienpilna un } \\
\text { atbalstoša vide }\end{array}$ & $-0,19^{*}$ & $-0,23$ & $-0,30$ & $-0,27$ & $-0,30$ \\
\hline $\begin{array}{l}\text { Iedrošināšana } \\
\text { un sadarbība }\end{array}$ & $-0,28$ & $-0,35$ & $-0,32$ & $-0,36$ & $-0,40$ \\
\hline $\begin{array}{l}\text { Koordinēta un } \\
\text { visaptveroša } \\
\text { aprūpe }\end{array}$ & $-0,22$ & $-0,25$ & $-0,29$ & $-0,25$ & $-0,31$ \\
\hline $\begin{array}{l}\text { Vispārējās } \\
\text { informācijas } \\
\text { sniegšana }\end{array}$ & $-0,20^{*}$ & $-0,17^{*}$ & $-0,18^{*}$ & $-0,21$ & $-0,25$ \\
\hline $\begin{array}{l}\text { Specifiskas } \\
\text { informācijas } \\
\text { sniegšana } \\
\end{array}$ & $-0,14^{*}$ & - & $-0,21^{*}$ & $-0,14^{*}$ & $-0,16^{*}$ \\
\hline $\begin{array}{l}\text { Profesionāḷu } \\
\text { atbalsts }\end{array}$ & $-0,34$ & $-0,35$ & $-0,29$ & $-0,29$ & $-0,43$ \\
\hline $\begin{array}{l}\text { Rehabilitācijas } \\
\text { saņemšanas } \\
\text { kārtība }\end{array}$ & - & - & $0,19 *$ & $0,13 *$ & - \\
\hline $\begin{array}{l}\text { Rehabilitācijas } \\
\text { pieejamība } \\
\text { dzīvesvietā }\end{array}$ & - & - & $0,14 *$ & $0,14 *$ & - \\
\hline
\end{tabular}

$\mathrm{p}<0,001 ; * \mathrm{p}<0.05$

\subsection{Daudzfaktoru lineārās regresijas analīzes rezultāti}

Lai noskaidrotu gimeṇu vajadzību ietekmējošos faktorus tika pielietota daudzfaktoru lineārās regresijas analīze. Analīzei tika izdalīti un apskatīti pieci ǵimen̦u vajadzību model̦i:

- $\quad$ modelis, kas izskaidro kopējās ǵimenes vajadzības;

- $\quad$ modelis, kas izskaidro ǵimenes vajadzību pēc atbalsta;

- modelis, kas izskaidro ǵimenes vajadzību pēc valsts un pašvaldības pakalpojumiem; 
- $\quad$ modelis, kas izskaidro ǵimenes finanšu vajadzības;

- modelis, kas izskaidro ǵimenes vajadzību pēc informācijas.

Visi izveidotie gala modẹ̦i atbilda regresijas analīzes kolinearitātes, linearitātes un normālsadalījuma nosacījumiem.

\subsubsection{Modelis, kas izskaidro kopējās ğimenes vajadzības}

Kā atkarīgais mainīgais šajā modelī tika izmantots ğimeṇu norādītais kopējais vajadzību skaits (ĢVA). Sākotnējā modelī kā neatkarīgie mainīgie tika ievietoti pieci bērnu ar cerebrālo trieku raksturojošie faktori (LMFKS līmenis, KFKS līmenis, socializācija, vispārējais veselības stāvoklis, asociēto veselības traucējumu skaits), seši gimeni raksturojošie faktori (respondenta izglītības līmenis, respondenta nodarbinātība, ǵimenes ienākumu līmenis, bērna primārā aprūpētāja uztvertā stresa līmenis, gimenes un neformālais atbalsts) un seši rehabilitācijas pakalpojumus raksturojoši faktori (piecas APN daļas un profesionāļu atbalsts).

Gala modelis, ar deviniiem neatkarīgiem main̄̄giem, izskaidroja $61 \%$ izmaiņu $\left(\mathrm{R}^{2}=0,61\right)$ gimeņu kopējās vajadzībās. Gala modelis un katra neatkarīgā main̄̄gā, kam bija statistiski nozīmīga ietekme uz ğimeņu kopējo vajadzību skaitu, unikālā ietekme attēlota 2.8. tabulā.

2.8. tabula

Ģimenes kopējās vajadzības izskaidrojošs daudzfaktoru regresijas modelis

\begin{tabular}{|c|c|c|c|c|c|c|}
\hline Regressijas modelis: $\mathbf{F}(\mathbf{9 , 2 3 3}) \mathbf{3 9 , 1 8} ; \mathbf{p}=\mathbf{0 , 0 0 0}$ \\
\hline Faktors & $\mathrm{B}$ & $\mathrm{SE}$ & $\beta$ & $\mathrm{t}$ & $\mathrm{p}$ & $\begin{array}{c}\text { Unikālā } \\
\text { ietekme \% }\end{array}$ \\
\hline Ienākumu līmenis & & & & & & 2,3 \\
\hline zems vs augsts & 4,23 & 1,14 &, 24 & 3,882 & 0,000 & \\
\hline vidējs vs augsts & 1,96 & 0,88 &, 13 & 2,355 & 0,032 & \\
\hline Strādā vs nestrādā & 2,52 & 0,63 &, 19 & 4,151 & 0,000 & 2,8 \\
\hline ĢAS gimene & $-0,58$ & 0,08 &,- 39 & $-6,835$ & 0,000 & 8,2 \\
\hline
\end{tabular}


2.8. tabulas turpinājums

\begin{tabular}{|l|c|c|c|c|c|c|}
\hline Stress & 0,18 & 0,04 &, 18 & 4,245 & 0,000 & 3,0 \\
\hline LMFKS līmenis & 0,51 & 0,22 &, 11 & 2,261 & 0,040 & 0,7 \\
\hline $\begin{array}{l}\text { Asociēto veselības } \\
\text { traucējumu skaits }\end{array}$ & 0,85 & 0,22 &, 19 & 3,932 & 0,000 & 2,5 \\
\hline APN sadarbība & $-1,18$ & 0,25 &,- 22 & $-4,872$ & 0,000 & 3,9 \\
\hline GSAS profesionāli & $-0,56$ & 0,12 &,- 21 & $-4,556$ & 0,000 & 3,5 \\
\hline
\end{tabular}

\subsubsection{Modelis, kas izskaidro ǵimenes vajadzību pēc atbalsta}

Kā atkarīgais mainīgais šajā modelī tika izmantots ǵimeņu norādītais vajadzību pēc atbalsta skaits (ĢVA kopējais vajadzību skaits sadal̦ās "Vajadzība pēc atbalsta" un '"Ģimenes funkcionēšana"). Kā neatkarīgie mainīgie sākotnējā modelī tika ievietoti četri bērnu ar cerebrālo trieku raksturojošie faktori (LMKS līmenis, KFKS līmenis, socializācija un asociēto veselības traucējumu skaits), seši ǵimeni raksturojoši faktori (respondenta izglītības līmenis, respondenta nodarbinātība, ǵimenes ienākumu līmenis, bērna primārā aprūpētāja uztvertā stresa līmenis, ǵimenes un neformālais atbalsts) un pieci rehabilitācijas pakalpojumus raksturojoši faktori (četras APN daļas un profesionāļu atbalsts).

Gala modelis izskaidroja $44 \%$ izmaiņu $\left(\mathrm{R}^{2}=0,44\right)$ ǵimeņu vajadzīîās pēc atbalsta. Gala modelis un katra neatkarīgā main̄̄gā, kam bija statistiski nozīmīga ietekme uz ǵimeņu atbalsta vajadzību skaitu, unikālā ietekme attēlota 2.9. tabulā. 
Ģimenes vajadzības pēc atbalsta izskaidrojošs daudzfaktoru regresijas modelis

\begin{tabular}{|l|c|c|c|c|c|c|}
\hline \multicolumn{1}{|c|}{ Regresijas modelis: $\mathbf{F}(\mathbf{7 , 2 3 3}=\mathbf{2 6 , 6 5} \mathbf{p}=\mathbf{0 , 0 0 0}$} \\
\hline Faktors & $\mathrm{B}$ & $\mathrm{SE}$ & $\beta$ & $\mathrm{t}$ & $\mathrm{p}$ & $\begin{array}{c}\text { Unikālā } \\
\text { ietekme \% }\end{array}$ \\
\hline Izglītība & & & & & & 2,1 \\
\hline pamata vs vidējā & 1,29 & 0,49 &, 13 & 2,568 & 0,011 & \\
\hline augstākā vs vidējā & 0,21 & 0,14 &, 04 & 0,715 & 0,475 & \\
\hline Stress & 0,06 & 0,02 &, 16 & 3,164 & 0,002 & 2,7 \\
\hline APN sadarbība & $-0,46$ & 0,11 &,- 22 & $-4,126$ & 0,000 & 4,5 \\
\hline G̦AS ǵimene & $-0,28$ & 0,03 &,- 37 & $-7,422$ & 0,000 & 13,9 \\
\hline ĢAS profesionāl̦i & $-0,23$ & 0,05 &,- 21 & $-4,011$ & 0,000 & 4,2 \\
\hline $\begin{array}{l}\text { Asociēto veselības } \\
\text { traucējumu skaits }\end{array}$ & 0,34 & 0,09 &, 19 & 3,603 & 0,000 & 3,5 \\
\hline
\end{tabular}

\subsubsection{Modelis, kas izskaidro ğimenes vajadzību pēc pakalpojumiem}

Kā atkarīgais main̄̄gais šajā modelī tika ievietots ǵimeņu norādītais vajadzību pēc valsts un pašvaldības pakalpojumiem skaits (ĢVA sadaḷa "Vajadzības pēc pakalpojumiem"). Kā neatkarīgie mainīgie sākotnējā modelī tika ievietoti pieci bērnu ar cerebrālo trieku raksturojošie faktori (LMKS līmenis, KFKS līmenis, socializācija, vispārējais veselības stāvoklis un asociēto veselības traucējumu skaits), seši ğimeni raksturojoši faktori (respondenta nodarbinātība, gímenes dzīvesvieta, ǵimenes ienākumu līmenis, bērna primārā aprūpētāja uztvertā stresa līmenis, ǵimenes un neformālais atbalsts) un astoṇi rehabilitācijas pakalpojumus raksturojoši faktori (piecas APN daļas, rehabilitācijas pieejamība dzīvesvietā, rehabilitācijas pakalpojumu saņemšanas kārtība un profesionāḷu atbalsts).

Gala modelis izskaidroja 52\% izmaiņu $\left(\mathrm{R}^{2}=0,52\right)$ ǵimeņu vajadzībās pēc pakalpojumiem. Gala modelis un katra neatkarīgā main̄̄gā, kam bija statistiki nozīmīga ietekme uz vajadzību pēc pakalpojumiem skaitu, unikālā ietekme attēlots 2.10. tabulā. 
2.10. tabula

Ģimenes vajadzības pēc pakalpojumiem izskaidrojošs daudzfaktoru regresijas modelis

\begin{tabular}{|l|c|c|c|c|c|c|}
\hline \multicolumn{2}{|c|}{ Regresijas modelis: $\mathbf{F}(\mathbf{8 , 2 3 3}) \mathbf{3 2 . 2 3} \mathbf{p}=\mathbf{0 , 0 0 0}$} \\
\hline Faktors & $\mathrm{B}$ & $\mathrm{SE}$ & $\beta$ & $\mathrm{t}$ & $\mathrm{p}$ & $\begin{array}{c}\text { Unikālā } \\
\text { ietekme \% }\end{array}$ \\
\hline KFKS līmenis & 0,32 & 0,06 &, 28 & 5,341 & 0,000 & 5,8 \\
\hline Bērnudārzs vs mājas & 0,72 & 0,17 &, 25 & 4,244 & 0,000 & 3,7 \\
\hline Ienākumu līmenis & & & & & & 2,2 \\
\hline zems vs augsts & 0,98 & 0,28 &, 23 & 3,375 & 0,002 & \\
\hline vidējs vs augsts & 0,45 & 0,21 &, 13 & 1,958 & 0,051 & \\
\hline Strādā vs nestrādā & 0,48 & 0,16 &, 17 & 3,112 & 0,007 & 1,7 \\
\hline Stress & 0,05 & 0,01 &, 18 & 3,920 & 0,001 & 2,8 \\
\hline G̦AS gimene & $-0,61$ & 0,02 &,- 12 & $-2,466$ & 0,024 & 1,4 \\
\hline APN sadarbība & $-0,29$ & 0,06 &,- 22 & $-4,102$ & 0,000 & 3,5 \\
\hline
\end{tabular}

\subsubsection{Modelis, kas izskaidro ğimenes finanšu vajadzības}

Kā atkarīgais main̄̄gais šajā modelī bija ǵimeņu norādītais finanšu vajadzību skaits (ĢVA sadaḷa "Finanšu vajadz̄̄bas"). Kā neatkarīgie main̄̄gie sākotnējā modelī tika ievietoti četri bērnu ar cerebrālo trieku raksturojošie faktori (LMKS līmenis, KFKS līmenis, socializācija, asociēto veselības traucējumu skaits), seši ğimeni raksturojoši faktori (respondenta nodarbinātība, ǵimenes ienākumu līmenis, bērnu skaits ǵimenē, bērna primārā aprūpētāja uztvertā stresa līmenis, ǵimenes un neformālais atbalsts) un astoṇi rehabilitācijas pakalpojumus raksturojoši faktori (piecas APN daḷas, rehabilitācijas pieejamība dzīvesvietā, rehabilitācijas pakalpojumu saṇemšanas kārtība un profesionāḷu atbalsts).

Gala modelis izskaidroja 53\% izmaiņu $\left(\mathrm{R}^{2}=0,53\right)$ gimeņu finanšu vajadzībās. Gala modelis un katra neatkarīgā main̄̄gā, kam bija statistiski nozīmīga ietekme uz finanšu vajadzību skaitu, unikālā ietekme attēlots 2.11. tabulā. 
Ģimenes finanšu vajadzības izskaidrojošs daudzfaktoru regresijas modelis

\begin{tabular}{|l|c|c|c|c|c|c|}
\hline \multicolumn{1}{|c|}{ Regresijas modelis: F(7,233) $=\mathbf{3 4 , 2 9} \mathbf{p}=\mathbf{0 , 0 0 0}$} \\
\hline Faktors & $\mathrm{B}$ & $\mathrm{SE}$ & $\beta$ & $\mathrm{t}$ & $\mathrm{p}$ & $\begin{array}{c}\text { Unikālā } \\
\text { ietekme \% }\end{array}$ \\
\hline LMFKS līmenis & 0,34 & 0,06 &, 28 & 5,244 & 0,000 & 5,8 \\
\hline $\begin{array}{l}\text { Asociēto veselības } \\
\text { traucējumi skaits }\end{array}$ & 0,14 & 0,05 &, 12 & 2,206 & 0,046 & 0,9 \\
\hline Strādā vs nestrādā & 0,63 & 0,16 &, 20 & 3,936 & 0,000 & 3,1 \\
\hline Ienākumu līmenis & & & & & & 10,8 \\
\hline \multicolumn{1}{c|}{ zems vs augsts } & 1,96 & 0,29 &, 45 & 6,498 & 0,000 & \\
\hline \multicolumn{1}{|c|}{ vidējs vs augsts } & 0,77 & 0,23 &, 17 & 2,595 & 0,017 & \\
\hline APN sadarbība & $-0,27$ & 0,06 &,- 21 & $-4,012$ & 0,000 & 3,5 \\
\hline ĢAS gimene & $-0,09$ & 0,02 &,- 17 & $-3,294$ & 0,002 & 2,4 \\
\hline
\end{tabular}

\subsubsection{Modelis, kas izskaidro g̊imenes vajadzību pēc informācijas}

Kā atkarīgais mainīgais šajā modelī tika izmantots ǵimeņu norādītais vajadzību pēc informācijas skaits (ĢVA kopējais vajadzību skaits sadą̧ā "Vajadzības pēc informācijas"). Kā neatkarīgie mainīgie sākotnējā modelī tika ievietoti pieci bērnu ar cerebrālo trieku raksturojošie faktori (LMFKS līmenis, KFKS līmenis, socializācija, vispārējais veselības stāvoklis un asociēto veselības traucējumu skaits), seši gimeni raksturojoši faktori (respondenta izglìtības līmenis, respondenta nodarbinātība, gimenes ienākumu līmenis, bērna primārā aprūpētāja uztvertā stresa līmenis, ǵimenes un neformālais atbalsts) un pieci rehabilitācijas pakalpojumus raksturojoši faktori (četras APN daļas un profesionāl̨u atbalsts).

Gala modelis izskaidroja 23\% izmaiņu $\left(\mathrm{R}^{2}=0,23\right)$ ǵimeņu vajadzībā pēc informācijas. Gala modelis un katra neatkarīgā main̄̄gā, kam bija statistiski nozīmīga ietekme uz ǵimeņu atbalsta vajadzību skaitu, unikālā ietekme attēlota 2.12. tabulā. 
2.12. tabula

Ģimenes vajadzības pēc informācijas izskaidrojošs daudzfaktoru regresijas modelis

\begin{tabular}{|l|c|c|c|c|c|c|}
\hline \multicolumn{7}{|c|}{ Regresijas modelis: F(6,233) $=\mathbf{1 2 , 2 3 ;} \mathbf{p}=\mathbf{0 , 0 0 0}$} \\
\hline Faktors & $\mathrm{B}$ & $\mathrm{SE}$ & $\beta$ & $\mathrm{t}$ & $\mathrm{p}$ & $\begin{array}{c}\text { Unikālā } \\
\text { ietekme } \%\end{array}$ \\
\hline KFKS līmenis & 0,02 & 0,01 &, 17 & 2,865 & 0,005 & 2,5 \\
\hline Ienākumu līmenis & & & & & & 3,5 \\
\hline zems vs augsts & 0,12 & 0,03 &, 28 & 3,280 & 0,001 & \\
\hline vidējs vs augsts & 0,10 & 0,03 &, 26 & 3,122 & 0,002 & \\
\hline APN vispārējā informācija & $-0,03$ & 0,01 &,- 16 & $-2,637$ & 0,009 & 2,1 \\
\hline G̦AS profesionāḷi & $-0,02$ & 0,01 &,- 20 & $-3,218$ & 0,001 & 3,2 \\
\hline G̦AS gimene & $-0,01$ & 0,02 &,- 17 & $-2,618$ & 0,009 & 2,0 \\
\hline
\end{tabular}




\section{DISKUSIJA}

\subsection{Pētījuma grupas raksturojums}

Pētījumā tika iesaistītas gímenes, kas datu ieguves periodā aprūpēja divus līdz septiņus gadus vecu bērnu ar cerebrālo trieku. Pētījumā mērķtiecīgi netika iesaistītas ǵimenes ar jaunāka vecuma bērniem, jo cerebrālās triekas diagnoze pirmajā dzīves gadā tiek noteikta tikai aptuveni 50\% gadījumos, savukārt līdz divu gadu vecumam jau 95\% gadījumu diagnoze ir noteikta, kā ar̄̄ ir manifestējušies ar smadzeņu bojājumu saistītie asociētie veselības traucējumi (Granild-Jensen et al., 2015).

Pētījuma nolūks bija noskaidrot Latvijā dzīvojošu ğimeņu vajadzības un izpētît tās ietekmējošos faktorus, tādēl pētījuma autori vēejēās uzrunāt visas gimenes, kas patstāvīgi dzīvo Latvijas teritorijā un aprūpē pirmsskolas vecuma bērnu ar cerebrālo trieku. Tā kā Latvijā nav vienota cerebrālās triekas registra, tad informācija par valstī dzīvojošo ǵimeņu skaitu tika iegūta balstoties uz VDEĀK sniegto informāciju, kas liecināja ka Latvijā ir regiistrēti 264 bērni, kuriem invaliditāte tikusi piešksirta pamatojoties uz SSK G80 kodu (cerebrālā trieka), un kuri ir dzimuši laika periodā no 2004. līdz 2010.gadam. Pētījumā tika iekḷautas 234 ǵimenes, kas sastāda 88,6\% no visu potenciāli iesaistāmo ǵimeņu skaita. No pētījumā iekḷautajām ğimenēm 84 jeb 36\% dzīvoja Rīgā, 89 (38\%) citā Latvijas pilsētā, bet 61 (26\%) norādīja, ka dzīvo lauku teritorijā. Šāds pētījumā iesaistîto gimeņu dzīvesvietu sadalījums ļauj pieņemt, ka ir iegūta visaptveroša informācija par Latvijā dzīvojošo ǵimeņu, kas audzina pirmsskolas vecuma bērnu ar cerebrālo trieku, vajadzībām un to noteicējfaktoriem.

Tā kā datu ieguves pamata metode bija anketēšana, tad līdzīgi kā citos šāda veida pētījumos (Farmer et al., 2004; Almasri, O’Neil \& Palisano, 2014; 
Hodgetts, Zwaigenbaum \& Nicholas, 2015), bērna primārais aprūpētājs tika aicināts pārstāvēt ǵimeni. Mūsu pētîjumā gimenes pārstāvēja galvenokārt bērna māte. Arī citos pētījumos, kur tiek apzinātas bērnu ar attīstības traucējumiem gimeņu vajadzības, respondenti vairumā gadījumu ir tieši bērnu mātes (Palisano et al., 2010; Chiu, Turnbull \& Summers, 2013; Hodgetts, Zwaigenbaum \& Nicholas, 2015). Astoņpadsmit procenti respondentu norādīja, ka bērnu audzina vieni, bet vairums bija precējušies vai dzīvoja kopā ar pastāvīgu partneri.

Analizējot bērna primārā aprūpētāja izglītības līmeni, konstatējām, ka tikai $20(8,5 \%)$ vecākiem bija pamatsskolas izglītība, bet 92 (39,3\%) bija ieguvuši augsāko izglīî̄bu. Šie dati sasaucas ar kopējo Latvijas iedzīvotāju izglīitības līmeņu sadalījumu - 2013. gada statistika rāda, ka 40,7\% Latvijas iedzīvotājiem vecumā no 30 līdz 34 gadiem ir augstākā izglìtîba (Centrālā statistikas pārvalde, 2013).

Atzīmēšanas vērts ir fakts, ka tikai puse mūsu aptaujāto respondentu datu ieguves periodā strādāja algotu darbu. Salīdzinoši citos līdzīgos pētījumos, bērnu primārā aprūpētāja nodarbinātība bija augstāka. Ziemel̦amerikā veiktos pētījumos tā variēja no 62-71\% (Almasri et al., 2011; Caicedo, 2014), savukārt deviņu Eiropas valstu apkopotie dati atklāj, ka algotu darbu strādā $85 \%$ bērnu ar cerebrālo trieku primārie aprūpētāji (Parkes et al., 2011). Iespējams, ka mūsu pētījuma dalībnieku zemāku nodarbinātību var izskaidrot ar to, ka mūsu mērķa auditorija bija gimenes ar jaunāka vecuma bēniem nekā citos pētījumos, kur bērnu ar cerebrālo trieku vecuma diapazons bija plašāks. Tomēr nevar izslēgt, ka zemā nodarbinātība ir saistāma ar sociāliem un ekonomiskiem iemesliem, kas ir raksturīgi tieši mūsu reǵionā.

Nodarbinātība un gimenes ienākumu līmenis tiek atzīmēti kā būtiski ǵimenes vajadzības ietekmējoši faktori, tādēḷ pētījuma autoru izstrādātajā aptaujas anketā bija divi jautājumi, kas saistīti ar ǵimenes finansiālā stāvokḷa noskaidrošanu. Anketas 17. jautājumā respondenti tika aicināti norādīt ğimenes vidējos mēneša ienākumus, atzīmējot vienu no četriem atbilžu variantiem. 
Vairums (136 jeb 58\%) norādīja, ka ǵimenes mēneša ienākumi ir robežās no 420 līdz 839 EUR. Gandrīz piektā daļa aptaujāto minēja, ka ǵimenes mēneša ienākumi ir zemāki par 420 EUR, savukārt 24\% atzīmēja, ka tie ir virs 840 EUR mēnesī. Salīdzinot iegūtos datus ar Centrālās statistikas pārvaldes (CSP) datiem par mājsaimniecību rīcībā esošiem ienākumiem 2013. gadā, kas bija 837,80 EUR mēnes̄i uz vienu mājsaimniecību (Centrālā statistikas pārvalde, 2013), jāsecina, ka vairumam ǵimeņu, kas audzina pirmsskolas vecuma bērnu ar cerebrālo trieku, ienākumi ir zemāki nekā vidēji Latvijas mājsaimniecībās. Šāds rezultāts ir likumsakarīgs, jo pusē gimeņu algotu darbu strādāja tikai viens no vecākiem.

Tā kā netika iegūta informācija par ǵimenes locekḷu skaitu, tad uzskatîjām, ka, nezinot mājsaimniecībā dzīvojošo skaitu, gimenes kopējie mēneša ienākumi nesniedz korektu priekšstatu par gimenes finansiālo situāciju. Tādēḷ, identificējot vajadzības ietekmējošos faktorus, ǵimenes finanšu stāvokḷa raksturošanai izmantojām aptaujas anketas 16. jautājumu, kur respondenti sniedz subjektīvu vērtējumu par ǵimenes ienākumu līmeni, to raksturojot kā "zemu" (18,8\%), "vidēju" (67,1\%) vai "augstu" (14.1\%).

Nedaudz vairāk nekā puse no bērniem ar cerebrālo trieku apmeklēja pirmsskolas izglītības iestādi vai dienas centru bērniem ar īpašām vajadzībām, bet 95 bērni (40,6\%) vēl nebija uzsākuši bērnu dārza apmeklējumu. Daḷa vecāku norādīja, ka tuvumā nav piemērotas pirmsskolas izglîtības iestādes, kamēr citi uzskatīja, ka bērns nav pietiekami patstāvīgs, lai ietu bērnu dārzā, vai arī to neḷauj bērna veselības stāvoklis - liela dạ̧a $(60,3 \%)$ aptaujāto vecāku sava bērna veselības stāvokli vērtēja kā "drīzāk sliktu".

Lai gan š̄ pêtījuma nolūks nebija noskaidrot epidemiologiska rakstura datus, tomēr ir iegūta nozīmīga, Latvijā līdz šim neapkopota, informācija par bērniem ar cerebrālās triekas diagnozi. Apkopotā informācija atklāj, ka līdzīgi kā citās valstīs, cerebrālā trieka Latvijā nedaudz biežāk ir sastopama zēniem (55,6\%), un visizplatītākā ir spastiskā cerebrālās triekas forma $(79,9 \%)$. 
Cerebrālās triekas diskinētiskā forma tika konstatēta 10,7\% bērniem, kas ir nedaudz mazāk kā vidēji Eiropā. Piemēram, Zviedrijā diskinētiskās formas prevelence cerebrālās triekas populācijā ir 16\% (Himmelmann \& Uvebrant, 2014), bet astoņu Eiropas valstu apkopotie dati liecina par14,4\% (Bax, Tydeman \& Flodmark, 2006). Savukārt, jaukta cerebrālās triekas forma mūsu apsekotajiem bērniem tika konstatēta biežāk $(5,6 \%)$ nekā vidēji Eiropā (Bax, Tydeman \& Flodmark, 2006). Minētās atšķirības iespējams ir saistītas ar dažādi traktētām diskinētiskās formas klīniskām pazīmēm, kā arī atšķirīgām diagnostikas pieejamām dažādās valstīs (Pakula, Braun \& Yeargin-Allsopp, 2009). Izvērtējot pētījumā iekḷauto bērnu kustību ierobežojumus, konstatējām, ka 53\% bērni spēja patstāvīgi staigāt, 18\% staigāja ar palīdzību, savukārt 29\% bērni patstāvīgi pārvietoties nespēja vai pārvietošanās nebija funkcionāli nozīmīga. Šāda motoro traucējumu izplatība saskan ar vispārējo tendenci cerebrālās triekas populācijā - Novakas un kolēǵu veiktajā sistemātiskajā literatūras metanalīzē tika konstatēts, ka $58 \%$ bērni ar cerebrālās triekas diagnozi spēj staigāt neizmantojot palīgierīces, 11\% pārvietojas, izmantojot staigāšanas palīgierīces, 14\% pārvietojas riteņkrēslā, bet 17\% bērnu neatkarīga pārvietošanās nav iespējama (Novak et al., 2012). Arī ar smadzeņu bojājumu saistīto veselības traucējumu izplatība mūsu apsekotajiem bērniem ar cerebrālo trieku bija līdzịga kā vidēji populācijā (McMahon, Pruitt \& Vargus-Adams, 2015). Līdz ar to mūsu iegūtie dati l̦auj apstiprināt pieņēmumu, ka cerebrālās triekas formu izplatība un ar slimības diagnozi saistītie raksturlielumi Latvijā ir līdzīgi kā citās Eiropas valstīs.

\section{2. Ģimenes vajadzību aptaujas rezultāti}

Mūsu pētījumā gimeņu vajadzību identificēšanai tika izmantota Ģimeņu vajadzības aptauja (ĢVA) - specifiska, standartizēta anketa, ko izveidoja, gimeņu, kas audzina bērnus ar attīstības traucējumiem, vajadzību apzināšanai. 
Tā palīdz speciālistiem izprast jomas, kurās ǵimenēm ir nepieciešama palīdzība, kā arī l̦auj atpazīit ğimenes, kurām ir nepieciešams īpašs atbalsts un palīdzība.

Kā liecina Ģimeņu vajadzības aptaujas rezultāti, procentuāli vislielākais vajadzību skaits tika norādīts anketas sadaḷā "Vajadzība pēc informācijas". Vairāk kā puse respondentu bija atbildējuši apstiprinoši uz visiem šīs sadaḷas apgalvojumiem. Līdzīga tendence ir vērojama arī citos pētîjumos, kuros apskatītas vajadzības gimenēs ar bērniem ar funkcionēšanas traucējumiem (Ellis et al., 2002; Farmer et al., 2004; Nitta et al., 2005; Palisano et al., 2010, Hodgetts, Zwaigenbaum \& Nicholas, 2015; Piškuret al., 2017). Tas varētu nozīmēt, ka vairums ǵimeņu, kas audzina bērnu ar attīstības traucējumiem, nejūtas pietiekami informētas par bērna saslimšanu, viņa attīstības veicināšanu, pieejamiem pakalpojumiem un nākotnes perspektīvām, un pakalpojumu sniedzējiem būtu jādomā, kā uzlabot ǵimeņu informētību. Tomēr Palisano un kolēgii, novērojot līdzịgu tendenci savā pētījumā, izteica arī pieņēmumu, ka lielais "informāciju vajadzību" skaits iespējams ir saistāms ar aptaujāto vecāku uzskatu, ka "informācijas nekad nav par daudz", nevis patiesu informācijas trūkumu (Palisano et al., 2010). Neskatoties uz šo pieņēmumu, veselības aprūpes sniedzējiem būtu jāpārliecinās, ka ǵimenes ir saņēmušas profesionālas atbildes uz tās interesējošiem jautājumiem. Īpaši nozīmīgi tas ir pašlaik, kad informācijas iegūšanai plaši tiek lietota interneta vide, nereti sniedzot mulsinošu, uz zinātniskiem pierādījumiem nebalstîtu informāciju par bērna saslimšanu,kā arī viṇa ārstēšanas un rehabilitācijas iespējām (Pehora et al., 2015).

Mūsu pêtījumā liels skaits respondentu bija norādījuši, ka viniem ir nepieciešama informācija par pakalpojumiem, kas pašlaik ir pieejami viņu bērnam ar cerebrālo trieku $(88,9 \%)$ un pakalpojumiem, kādus viņam vajadzētu saņemt nākotnē (85\%). Salīdzinoši citu autoru publicētie dati ir nedaudz atšķirīgi. Tikai 54\% Farmeres, 63\% Elias un 59\% Palisano aptaujāto vecāku 
bija minējuši, ka viņiem nepieciešama informācija par pašlaik pieejamiem pakalpojumiem, savukārt par nākotnes pakalpojumiem interesējās attiecīgi 74\%, 78\% un 68\% vecāku (Ellis et al., 2002; Farmer et al., 2004; Palisano et al., 2010). Šāds salīdzinājums tomēr norāda, ka Latvijā dz̄ivojošās g̊imenes ir mazāk informētas par pakalpojumiem, kādi ir pieejami viņu bērnam ar attīstības traucējumiem, un pakalpojumu sniedzējiem būtu jāpārliecinās, ka geimene ir informēta par tai nozīmīgiem jautājumiem.

Mūsu aptaujātās ǵimenes salīdzinoši biežāk, kā citu pētnieku aptaujātie vecāki, norādīja, ka vēlas iegūt informāciju par bērna saslimšanu, kā arī par bērna apmācības un izglītības iespējām. Iespējams, ka šāda pastiprināta interese ir skaidrojama ar bērnu vecuma īpatnībām. Mūsu pētījumā tika iekḷautas ǵimenes ar pirmsskolas vecuma bērniem, kamēr citi autori bija pētījuši ǵimenes ar dažāda, tai skaitā, skolas vecuma bērniem. Tiek atzīmēts, ka jaunāka vecuma bērnu vecākiem ir izteiktāka vēlme pēc visa veida informācijas. Jaunie vecāki ir nobijušies un nedroši, vēl neorientējas jaunajā situācijā un pakalpojumu piedāvājumā, meklē visas iespējas, lai veicinātu bērna attīstību (Palisano et al., 2010).

Kā nākamās nozīmīgākās jomas, kas vairumam aptaujāto ǵimeņu raisīja vēlmi pēc papildus atbalsta, bija vajadzības, kas saistītas ar publisko pakalpojumu (ārstēšana, rehabilitācija, pirmsskolas iestāde utml.) nodrošināšanu un finansiālu atbalstu. Šāds rezultāts nav pārsteigums. Ir zināms, ka cerebrālā trieka ir "dārga" saslimšana, un tās izmaksas cilvēka dzīves garumā var sasniegt 900000 eiro (Kruse et al., 2009). Gan pakalpojumu pieejamība, gan finansiālie izaicinājumi ǵimenēm, kas audzina bērnu ar cerebrālo trieku, ir daudz lielāki nekā citām ǵimenēm ar līdzīga vecuma bērniem (Kancherla et al., 2012). Tā kā nereti, kā tas ir arī mūsu pētījuma grupā, viens no vecākiem algotu darbu nestrādā vai strādā nepilnu laiku, tad finansiālās problēmas vēl pastiprinās. 
Vairāk kā puse $(61,1 \%)$ gimeṇu norādīja, ka tām ir nepieciešama palīdzība bērna rehabilitācijas pakalpojumu nodrošināšanā, savukārt trešdaḷai gimeņu bija nepieciešama palīdzība pirmsskolas iestādes vai auklītes atrašanā. Īpaši satraucošs ir fakts, ka 73\% respondentu gimenēm ir nepieciešama palīdzība medicīnisko, sociālo un izglītîbas pakalpojumu koordinēšanā. Jāatzīmē, ka līdzīgs atklājums iezīmējas arī pēc Tiesībsarga pasūtījuma veiktajā pētījumā "Bērnu ar invaliditāti rehabilitācijas efektivitāte Latvijāa sociālantropologiskais aspekts", kur tiek secināts, ka "plānošanas sistēma Latvijā ir smagnēja un birokrātiska", kā arī "valsts un pašvaldības dienestu un arī medicīnas profesionāḷu darbība ir reaktīva, ne proaktīva" ("Bērnu ar invaliditāti rehabilitācijas efektivitāte Latvijā: sociālantropologiskais aspekts", 2016). Latvijā ir spēkā normatīvie regulējumi, kas paredz koordinētu aprūpi personām ar funkcionēšanas traucējumiem. Tā, piemēram, MK noteikumi Nr. 9 "Noteikumi par individuālo rehabilitācijas plānu personai ar prognozējamu invaliditāti un personai ar invaliditāti", nosaka koordinētu pakalpojumu programmas izstrādi personas ar funkcionēšanas ierobežojumiem atbalstam un integrācijas veicināšanai. Arī atsevišķas pašvaldības saviem iedzīvotājiem piedāvā pakalpojumus ar mērķi sniegt koordinētu atbalstu. Tā, piemēram, Rīgas pilsētā jau vairākus gadus tiek realizēts pakalpojums "Sociālās rehabilitācijas programmas bērniem ar funkcionāliem ierobežojumiem" ar mērķi "veicināt personas sociālās funkcionēšanas spēju atjaunošanu vai uzlabošanu, sociālā statusa atgūšanu un iekḷaušanos sabiedrībā, tai skaitā izglītības sistēmā" (RD Labklājības departaments). Diemžēel, pētîjuma rezultāti liecina, ka lai gan Latvijā pēdējos gados ir pieaudzis pašvaldības un valsts sniegtais atbalsts gimenēm ar bērniem ar funkcionēšanas traucējumiem, ko paredz arī normatīvie regulējumi, tomēr piedāvāto pakalpojumu klāsts ir nepilnīgs, un to koordinācija vēl joprojām nav efektīva. Jāatzīmēe ka valstīs ar vēsturiski stabilu sociālā atbalsta sistēmu, gímenes retāk norāda uz vajadzībām, kas saistītas ar medicīnisko, sociālo un izglìtības pakalpojumu koordinētu 
saņemšanu (Farmer et al., 2004; Palisano et al., 2010; Almasri et al., 2011; Hodgetts, Zwaigenbaum \& Nicholas, 2015).

Ir zināms, ka bērnam ar funkcionēšanas traucējumiem pieaugot, palielinās nepieciešamība pēc finansiāla atbalsta (Almasri et al., 2011). Kamēr bērns ir mazs, viņu var pārvadāt standarta bērnu ratos, sēdēšanas atbalstam izmantojot standarta zīdaiņu krēsliņus. Šajā periodā vecāki vēl reti domā par staigāšanas palīglīdzekḷu nepieciešamību vai bērnam piemērota izmēra ratiņkrēslu. Bērnam pieaugot rodas nepieciešamība pēc speciāliem palīglīdzekḷiem viņa neatkarības veicināšanai vai medicīnisko komplikāciju novēršanai. Aktualizējas jautājums par mājokḷa pielāgošanu un pārbūvi, kas prasa lielus finansiālus izdevumus. Tā kā mūsu aptaujātajās ğimenēs bērni bija vecumā līdz septiņiem gadiem, salīdzinoši maz ǵimeņu norādīja, ka būtu nepieciešams finansiāls atbalsts mājokḷa pārbūvei. Tomēr vairāk nekā pusei bija nepieciešams finansiāls atbalsts speciālā inventāra vai palīglīizekḷu iegādei. Neskatoties uz to, ka funkcionēšanai nepieciešamie tehniskie palīglīdzekḷi tiek nodrošināti valsts finansējuma ietvaros, dažkārt vecākiem palīglīdzekḷi jāiegādājas arī par personīgiem līdzekḷiem. Tā, piemēram, ja bērnam sēdēšanas atbalstam nepieciešams speciāls pozicionēšanas krēsls, viens šāds krēsls ir pieejams valsts tehnisko palīglīdzekḷu piešķiršanas kārtībā. Tomēr, ja bērns apmeklē bērnudārzu, tad šădi krēsli ir nepieciešami divi - mājās un bērnudārzā. Diemžēl izglītības iestāžu finanšu budžetos nav paredzēta šāda aprīkojuma iegāde. Līdz ar to otru krēslu, ko bērns varētu lietot bērnudārzā vai skolā, vecākiem nākas iegādāties par personīgajiem līdzekḷiem. Nereti vecākus neapmierina pieškirto palīglīdzekḷu kvalitāte vai ilgais palīglīidzekḷa saņemšanas gaidīšanas laiks - arī tādos gadījumos nereti palīglīdzekḷi tiek iegādāti par personīgajiem līdzekḷiem. Jāatzīmēe ka līdzīgu nepieciešamību pēc finansiāla atbalsta bērnam palīglīdzekḷu iegādei, izteica arī Nittas aptaujātie vecāki Japānā un Vangas aptaujātie vecāki Ķīnā (Nitta et al., 2005; Wang \& Michaels, 2010), savukārt ASV veiktajos Farmeres un Palisano pētījumos, šādu 
vajadzību atzīmēja tikai 19\% un 34\% vecāku (Farmer et al., 2004; Palisano et al., 2010).

Nav pārsteidzoši, ka vairums gimen̦u norādīja nepieciešamību pēc finansiāla atbalsta bērna ārstēšanas un rehabilitācijas izdevumu segšanai. Rehabilitācijas apjoms un intensitāte valsts veselības aprūpes sistēmas ietvaros ir ierobežota, tādēḷ papildus tai, ǵimenes izvēlas saṇemt terapiju arī maksas pakalpojumu sektorā. Nereti, meklējot iespējas uzlabot bērna veselības stāvokli, vecāki izšķiras par ārstniecības pakalpojumiem, kas neietilps valsts finansēto veselības aprūpes pakalpojumu grozāa, vai meklē ārstēšanas un rehabilitācijas iespējas ārvalstīs.

Liela daḷa aptaujāto ǵimeņu bija norādījušas, ka tām ir nepieciešams ne tikai finansiāls, bet arī morāls un psiholoǵisks atbalsts. Vairums respondentu minēja, ka vēlētos biežāk tikties ar ǵimenēm, kam ir līdzīgs bērns, kā arī lasīt par gimenēm ar līdzīgām problēmām. Interviju laikā vairāki vecāki norādīja, ka tieši sarunas ar vecākiem, kas sastopas ar līdzīgām problēmām un izaicinājumiem, kā arī pozitīvi piemēri, ir veids, kā tikt galā, kad ir visgrūtāk. Savukārt, gandrīz puse respondentu atzīmēja, ka vēlētos arī regulāru profesionālu psihologisko atbalstu.

Tā kā rūpes par slimo bērnu paṇem lielu dienas daḷu, un puse no bērniem neapmeklēja bērnudārzu, nav nekāds pārsteigums, ka vairums mūsu aptaujāto vecāku vēlētos vairāk laika, ko varētu veltît tikai sev. Šāds vajadzību veids tiek atzīmēts kā nozīmīgs arī citu autoru publicētajos ziņojumos (Perrin, Lewkowicz \& Young, 2000; Ellis et al., 2002; Nitta et al., 2005; Wang \& Michaels, 2010).

Līdzīgi kā Palisano un viña kolēǵu veiktajā pêtījumā tikai neliels skaits aptaujāto atzīmēja vajadzības, kas saistītas ar ğimenes funkcionēšanu (Palisano et al., 2010). Iespējams, ka šāda palīdzība ǵimenēm patiešām nav nepieciešama. Tomēr nevar izslēgt, ka aptaujātie vecāki šīs vajadzības neapzinās vai neatzīst. Tiek uzskatīts, ka vecāki, kuriem ir bērns ar attīstības traucējumiem vai 
hronisku saslimšanu, vairāk domā kā veicināt bērna attīstību, bet mazāk pievēršas visas ğimenes vajadzībām, un neuztver tās kā vajadzības, kas var būt par iemeslu paaugstinātam stresam un gimenes izjukšanai (Graves \& Hayes, 1996).

Tikai neliela daļa respondentu bija atzīmējuši, ka viņiem ir nepieciešama palīdzība bērna stāvokḷa izskaidrošanai citiem cilvēkiem, kas sasaucas ar citu autoru publicēto informāciju (Nitta et al., 2005; Palisano et al., 2010). Tomēr jāatzīmēe ka gandrīz trešdaļa respondentu bija norādījuši, ka viņiem nepieciešama palīdzība, lai zinātu, kā izskaidrot bērna stāvokli profesionāļiem (bērnu dārza audzinātājiem, mediķiem). Šāds rezultāts norāda, ka neskatoties uz valstī aktīvi notiekošajiem integrācijas procesiem, izglītības un pat veselības aprūpes speciālisti nav pietiekami informēti un sagatavoti darbam ar bērniem ar funkcionēšanas ierobežojumiem.

Kopumā varam secināt, ka Latvijā dzīvojošās gimenes, kas audzina bērnu ar cerebrālo trieku, pauž līdzịgas vajadzības kā ǵimenes citās zemēs. Tomēr uzmanību saista fakts, ka mūsu gimenēm īpaši pietrūkst informācijas par pakalpojumu pieejamību, kā arī ir izteikti nepieciešama palīdzība ārstniecības un rehabilitācijas pakalpojumu koordinācijā. Tas tomēr liecina, ka Latvijā nav efektīvas sistēmas, kas nodrošinātu pilnvērtīgu un koordinētu atbalstu ǵimenēm, kurās aug bērns ar attīstības traucējumiem.

\subsection{Bērnu ar cerebrālo trieku raksturojošo faktoru saistība ar gimenes vajadzībām}

Pamatojoties uz visaptverošu literatūras izpēti par bērnu raksturojošo faktoru ietekmi uz ǵimenes vajadzībām, pētījumā tika iekḷauti un apskatīti tādi raksturojoši lielumi, kā bērna vecums, komunikācijas funkcija, motorā funkcija, asociēto veselības traucējumu skaits, vispārējā veselības stāvokḷa vērtējums un socializācija. 
Publikācijās tiek atzīmēts, ka pastāv saistība starp bērna ar funkcionēšanas traucējumiem vecumu un gimenes vajadzību skaitu - mazāks bērna vecums ir saistāms ar palielinātu kopējo gimenes vajadzību skaitu (Ellis et al., 2002; Ueda et al., 2013). Tomēr mūsu pētījumā šāda sakarība netika atrasta, līdz ar to bērna vecums turpmākajā analīzē, lai identificētu gimenes vajadzības ietekmējošos faktorus, netika iekḷauts. Iespējams, ka šāds rezultāts ir izskaidrojams ar pētījuma grupas homogenitāti - mūsu pētījumā tika iekļauti pirmsskolas vecuma bērni, līdz ar to ietvertais vecuma diapazons bija neliels, savukārt citos pētījumos tika apskatītas ǵimenes ar dažāda vecuma bērniem.

Pārējie apskatītie bērnu ar cerebrālo trieku raksturojošie faktori bija saistīti gan ar gimenes kopējo vajadzību skaitu, gan ar vajadzību skaitu visās apskatītajās vajadzību jomās, un tie tika iekḷauti regresiju analīzēs kā iespējamie ǵimenes vajadzības ietekmējošie faktori.

Literatūrā kā nozīmīgi ǵimenes vajadzības ietekmējoši faktori tiek minēti bērna funkcionēšanas ierobežojumi un veselības stāvoklis - jo bērnam ir izteiktāki funkcionēšanas ierobežojumi un komplicētāki veselības traucējumi, jo pieaug ǵimenes vajadzības (Sloper \& Turner, 1992; Farmer et al., 2004; Nitta et al., 2005; Eddy \& Engel, 2008; Palisano et al., 2010; Almasri, O’Neil \& Palisano, 2014). Arī mūsu pētījumā korelāciju analīzes rezultāti parādīja, ka šāda sakarība pastāv, tomēr šo faktoru ietekme uz gimenes vajadzību skaitu nebija tik pārliecinoša. Lai gan bērna kustību ierobežojuma līmenis bija saistîts ar kopējo gimenes vajadzību skaitu, taču tā unikālā ietekme uz kopējo gimenes vajadzību skaitu bija zema. Tomēr bērna kustību ierobežojuma līmenis bija nozīmīgs gimeņu finanšu vajadzības ietekmējošs faktors - gimenes, kuru bērni spēja staigāt neizmatojot palīgierīces, atzīmēja mazāk vajadzību pēc finansiāla atbalsta nekā ǵimenes, kuru bērniem šādas iespējas nebija. Iegūtie dati sakrīt ar citu autoru publicēto informāciju (Palisano et al., 2010; Almasri, O’Neil \& Palisano, 2014). Savukārt, pretēji Almasri un kolēǵu konstatētajam, bērna kustību ierobežojuma līmeņa ietekme uz gimenes vajadzībām pēc 
pakalpojumiem un atbalsta mūsu pētījumā netika atrasta (Almasri, O’Neil \& Palisano, 2014).

Negaidīts rezultāts bija bērna komunikācijas traucējumu ietekme uz ǵimenes vajadzībām pēc pakalpojumiem - ǵimenes, kuru bērniem bija izteiktāki komunikācijas traucējumi, biežāk atzīmēja, ka tām nepieciešama palīdzība ārstniecības, rehabilitācijas vai izglîtības pakalpojumu atrašanā un nodrošināšanā. Šis faktors izrādījās visnozīmīgākais no identificētajiem bērnu, ǵimeni un pakalpojumus raksturojošajiem faktoriem, ar spēcīgu unikālo ietekmi uz šo gimenes vajadzību veidu. Bērna komunikācijas traucējumi ietekmēja arī ǵimenes vajadzību pēc informācijas - izteiktāki komunikācijas traucējumi, palielināja gímenes vajadzību skaitu šajā vajadzību jomā. Ir zināms, ka bērna izziņas un uzvedības traucējumi ir ǵimenes vajadzības pastiprinoši faktori (Almasri, O’Neil \& Palisano, 2014; Hodgetts, 2015), savukārt bērniem ar izteiktiem komunikācijas traucējumiem biežāk novēro arī kognitīvo funkciju traucējumus un apgrūtinātu socializāciju (Mei et al., 2015; Lipscombe et al., 2016). N̦emot vērā bērna vecumu, izziṇas līmenis mūsu pētîjumā iekḷautajiem bērniem netika noteikts. Tomēr var izteikt pien̦ēmumu, ka bērniem, kuriem bija izteiktāki komunikācijas traucējumi, bija arī izteiktāki kognitīvo funkciju ierobežojumi, kas iespējams noteica pastiprinātas gimenes vajadzības pēc pakalpojumiem un informācijas.

Mūsu pētījuma datu analīze atklāja, ka pieaugot ar smadzeņu bojājumu asociēto veselības traucējumu skaitam, palielinājās gimenes kopējās vajadzības, kā arī vajadzības pēc atbalsta un finanšu vajadzības, un šim faktoram bija nozīmīga ietekme uz gimenes vajadzībām minētajās vajadzību jomās. Savukārt, lai gan bērna vispārējā veselības stāvokḷa raksturojums bija saistīts ar vairākām gimenes vajadzību jomām, tomēr nevienā no tām ietekme nebija nozīmīga.

Lai gan rezultātu analīze atklāja vāju korelāciju starp bērna socializāciju un gimenes kopējo vajadzību skaitu un vajadzību skaitu atsevišķās vajadzību jomās, tomēr bērna socializācija izrādījās nozīmīgs vajadzības ietekmējošs 
faktors vienīgi ğimenes vajadzībās pēc pakalpojumiem. Ja bērns neapmeklēja bērnu dārzu vai dienas centru, ǵimenes vajadzības pēc pakalpojumiem palielinājās.

\section{4. Ģimeni raksturojošo faktoru saistība ar ğimenes vajadzībām}

Kā iespējamie gimenes vajadzības ietekmējošie faktori mūsu pētījumā tika apskatīti sekojoši gimeni raksturojoši lielumi: bērna primārā aprūpētāja vecums, izglīitība, nodarbinātība, gimenes stāvoklis un uztvertā stresa līmenis, bērnu skaits ǵimenē, gimenes ienākumu līmenis, dz̄ives vieta, gimenes un draugu atbalsts.

Lai gan literatūrā tiek minēts, ka gados vecākas mātes pauž vairāk vajadzību pēc atbalsta (Ziviani et al., 2014; Hodgetts, Zwaigenbaum \& Nicholas, 2015), mūsu pētījumā, šāda sakarība netika novērota. Primārā aprūpētāja vecums nebija saistīts ne ar kopējo gimenes vajadzību skaitu, ne ar vajadzību skaitu atsevišksās vajadzību jomās, tādēḷ regresiju analīzē šis faktors netika ieklauts.

Ziviani un viṇa kolēǵu pētījumā vairāk vajadzību izteica tie vecāki, kuri bērnus audzināja vieni (Ziviani et al., 2014), savukārt mūsu pētījuma dati to neapstiprināja. Tādēl arī ǵimenes stāvoklis kā faktors netika izmantots turpmākajā analīzē.

Toties l’oti nozīmīgs vajadzības ietekmējošs faktors bija tuvinieku sniegtais atbalsts - bērna primārajam aprūpētājam saņemot atbalstu un palīdzību no citiem ǵimenes locekḷiem, ǵimenes vajadzību skaits samazinājās.

Šis bija vien̄̄gais no visiem analīzē iekḷautajiem faktoriem ar noz̄̄mīgu ietekmi gan uz kopējo gimenes vajadzību skaitu, gan uz vajadzību skaitu visās apskatītajās vajadzību jomās. Arī citi pētnieki ir apstiprinājuši, ka gimenes, kurās ir labas un atbalstošas savstarpējās attiecības, veiksmīgāk risina 
jautājumus, kas saistîti ar slimā bērna aprūpi un ārstěšanu, kā arī šīm ǵimenēm retāk ir nepieciešams "ārējais" atbalsts (Glenn et al., 2009; Palisano et al., 2010). Šì ir nozīmīga informācija pakalpojumu sniedzējiem. Pakalpojumu sniedzējiem būtu jāapzinās, ka gadījumos, kad pakalpojuma saṇēmēja ir ǵimene, kurai trūkst šis iekšējais atbalsts, iespējams ir lielāka nepieciešamība pēc pakalpojumiem, informācijas, sociāla un finansiāla atbalsta.

Respondenta izglìtības līmenis kopumā nebija nozīmīgs gimenes vajadzības ietekmējošs faktors, jo vienīgātā ietekme tika atrasta uz gimenes vajadzībām pēc atbalsta - pamatskolas izglītîba bija vajadzības pastiprinošs faktors tikai šajā vajadzību jomā. Apskatītajā literatūrā vecāku izglīî̄bas līmeņa ietekme uz gimenes vajadzībām ir pretrunīga - Beilija un Uedas pētījumos zemāks vecāku izglîtības līmenis tiek saistīts ar palielinātu gimenes vajadzību apjomu, savukārt Farmeres, Palisano un Almasri pētījumos šāda saistība netika novērota (Bailey et al., 1999; Ueda et al., 2013, Farmer et al., 2004, Palisano et al., 2010; Almasri, O’Neil \& Palisano, 2014).

Bērna primārā aprūpētāja uztvertā stresa līmenis izrādījās nozīmīgs ǵimenes vajadzības ietekmējošs faktors. Augstāks uztvertā stresa līmenis palielināja kopējo gimenes vajadzību skaitu, kā arī vajadzību pēc pakalpojumiem un atbalsta skaitu. Paaugstināts vecāku stresa līmenis tiek saistīts ar lielāku nepieciešamību pēc atbalsta arī apskatītajā literatūrā (Glenn et al., 2009; Cantwell, Muldoon \& Gallagher, 2014). Savukārt negaidīts rezultāts ir vecāku uztvertā stresa līmeņa ietekme uz ǵimenes vajadzībām pēc pakalpojumiem.

Pētījumos tiek atzīmēts, ka lielāks bērnu skaits ǵimenē ir saistīts ar lielāku vajadzību skaitu, īpaši pēc papildus finansiālā atbalsta (Lindley \& Mark, 2010). Lai gan mūsu pētījumā gimenes, kurās bija divi vai vairāk bērni, izteica vairāk finanšu vajadzību kā gimenes, kurās bija tikai viens bērns, šis faktors tomēr nebija ar nozīmīgu ietekmi uz minēto vajadzību jomu. 
Ja ğimenē aug bērns ar veselības un funkcionēšanas traucējumiem, tad būtiska kḷūst dažādu veselības un sociālo pakalpojumu pieejamība. Farmeres un Almasri pētījumos atklāts, ka ǵimenes, kas dzīvo pilsētās, kur veselības, sociālās aprūpes un izglîtības iestādes ir pieejamākas, kopumā atzīmē mazāk vajadzību kā gimenes, kas dzīvo attālākos rajonos (Farmer et al., 2004, Almasri, O’Neil \& Palisano, 2014). Arī mūsu pētījuma rezultāti iezīmē līdzīgu tendenci - Rīgā dzīvojošās gimenes atzīmēja mazāk vajadzību pēc pakalpojumiem, nekā gimenes, kas dzīvo citās pilsētās vai lauku teritorijā. Tomēr faktora ietekme uz šo vajadzību jomu, neapstiprinājās. Mūsu pētījumā ne gímenes dzīves vieta, ne bērnu skaits ǵimenē nebija ar nozīmīgu ietekmi uz ǵimenes vajadzībām.

Kā vieni no nozīmīgākajiem ğimenes vajadzības mazinošiem faktoriem tiek minēti augstāks ǵimenes sociālekonomiskais statuss un lielāki ienākumi (Farmer et al., 2004; Almasri et al., 2011; Ueda et al., 2013; Almasri, O’Neil \& Palisano, 2014). Šo informāciju apstiprina arī mūsu pētījuma dati. Vidējs un, vēl vairāk, zems ǵimenes ienākumu līmenis palielināja ǵimenes kopējo vajadzību skaitu, kā arī vajadzību skaitu pēc pakalpojumiem, informācijas un finansiāla atbalsta. Vienīgā no pētījumā apskatītajām vajadzību jomām, ko ǵimenes ienākumu līmenis neietekmēja, bija vajadzība pēc atbalsta - līdzīgu vēlmi pēc formāla un neformāla atbalsta pauda gan tie respondenti, kuri gimenes ienākumu līmeni vērtēja kā augstu, gan tie, kuri uzskatīja, ka gimenes ienākumu līmenis ir vidējs vai pat zems.

Lai gan ğimenes kopējo finanšu stāvokli var ietekmēt apstāklis, vai visi pieaugušie ǵimenes locekļi strādā algotu darbu, mūsu pētījumā korelācija starp faktoru, kas raksturo bērna primārā aprūpētāja nodarbinātību un gimenes ienākumu līmeni, bija vāja. Tomēr bērna primārā aprūpētāja nodarbinātība pati par sevi bija nozīmīgs ǵimenes vajadzības samazinošs faktors. Ja bērna primārais aprūpētājs strādāja, samazinājās gan kopējais ǵimenes vajadzību skaits, gan arī finanšu vajadzības un vajadzības pēc pakalpojumiem. 


\subsection{Rehabilitācijas pakalpojumus raksturojošo faktoru saistība ar ǵimenes vajadzībām}

Kā pakalpojumus raksturojoši faktori pētījumā tika apskatīti tādi rehabilitācijas pakalpojumu raksturojoši lielumi, kā rehabilitācijas pakalpojumu pieejamība dzīvesvietā, rehabilitācijas pakalpojumu saņemšanas kārtība, no profesionāļiem saņemtais atbalsts, kā arī rehabilitācijas pakalpojumu atbilstīiba uz gimeni vērstu pakalpojumu sniegšanas principiem - "Cieņpilna un atbalstoša vide", "Sadarbība", "Koordinēta aprūpe", "Vispārējas informācijas sniegšana" un "Specifiskas informācijas sniegšana".

Pārsteidzoši, bet pretēji Almasri un kolēǵu publicētajai informācijai (Almasri, O’Neil \& Palisano, 2014), ne rehabilitācijas pieejamība dzīvesvietā, ne rehabilitācijas pakalpojumu saņemšanas kārtība nebija tie faktori, kas ietekmēja mūsu respondentu gimenes vajadzības. Lai gan aptaujātajām ǵimenēm, kuru dzīvesvietā rehabilitācijas pakalpojumi nav pieejami, bija vairāk finanšu vajadzību, kā arī vairāk vajadzību pēc pakalpojumiem, tomēr tas nebija nozīmīgs šìs vajadzības ietekmējošs faktors. Līdzīga tendence tika novērota arī saistībā ar rehabilitācijas pakalpojumu saņemšanas veidu. Ģimenes, kuru bērniem rehabilitācijas pakalpojumi bija pieejami regulāri, izteica mazāk finanšu un pakalpojumu vajadzības, nekā gimenes, kuru bērniem rehabilitācija tika nodrošināta kursu veidā. Tomēr arī š̄ faktora ietekme uz finanšu un pakalpojumu vajadzību skaitu nebija nozīmīga. Savukārt ar gímenes kopējo vajadzību skaitu un vajadzībām pēc informācijas un atbalsta minētie rehabilitācijas pakalpojumus raksturojošie faktori vispār nebija saistīti. Toties nozīmīgs vajadzības mazinošs faktors izrādījās no profesionāļiem saņemtais atbalsts. Ģimenes, kuras norādīja, ka izjūt lielu palīdzību un atbalstu no profesionāliem, kas strādā ar viņu bērnu un gimeni, atzīmēja mazāk kopējo vajadzību, kā arī šajā gadījumā, ǵimenēm bija mazāk vajadzību pēc 
pakalpojumiem, atbalsta, informācijas un finanšu vajadzību. Lielāks no profesionāļiem saņemtais atbalsts bija nozīmīgs ǵimenes kopējo vajadzību, kā arī vajadzību pēc informācijas un atbalsta, mazinošs faktors. Tāpat pozitīva saistība ar g̣imenes vajadzību samazināšanu tika novērota tajos gadījumos, kad ǵimene atzīmēja, ka saņemtie pakalpojumi bija atbilduši uz ǵimeni vērstu pakalpojumu sniegšanas principiem. İpaši jāuzsver principa "Iedrošināšana un sadarbība" nozīme. Sniedzot pakalpojumus, ievērojot sadarbības un partnerības principus, t. i., iesaistot lēmumu pieņemšanā ǵimeni kā līdzvērtīgu partneri, iespējams būtiski mazināt gan gímenes kopējās vajadzības, gan vajadzības pēc atbalsta, pakalpojumiem un papildu finansējuma. Savukārt principa "Vispārējas informācijas sniegšana" ievērošana bija nozīmīgs vajadzības pēc informācijas mazinošs faktors. Mūsu iegūtie rezultāti sasaucas ar Palisano un Almasri ziņoto par uz gímeni vērstu pakalpojumu pozitīvo ietekmi uz gímeņu vajadzību mazināšanu ǵimenēm, kas audzina bērnu ar cerebrālo trieku (Palisano et al., 2010; Almasri, O’Neil \& Palisano, 2014).

Kopumā jāsecina, ka nozīmīgāki ǵimenes vajadzības mazinoši izrādījās tieši tie faktori, kas saistāmi ar attieksmes jautājumiem - veidu, kādā profesionāļi, tai skaitā, veselības aprūpes speciālisti komunicē ar ğimenēm, cik sekmīgi veido sadarbību un sniedz atbalstu. Savukārt pakalpojumu pieejamībai dzīvesvietā un pakalpojumu regularitātei nebija pārliecinošas ietekmes uz gimenes vajadzību veidu un skaitu.

\subsection{Bērnu ar cerebrālo trieku ğimeņu vajadzības izskaidrojošo faktoru analīze}

Ar daudzfaktoru lineārās regresijas metodi tika noteikti ǵimeņu vajadzības iekmējošie faktori. Tā kā tiek minēts, ka ǵimeņu vajadzības ietekmējošie faktori variē atkarībā no vajadzību jomas (Almasri, O’Neil \& Palisano, 2014; Hodgetts, Zwaigenbaum \& Nicholas, 2015), tad pēc vajadzību 
ietekmējošo faktoru identifikācijas tika izdalīti un apskatīti pieci ǵimenes vajadzību modeḷi.

\subsection{1. Ģimenes kopējās vajadzības izskaidrojošo faktoru analīze}

Izveidotais regresijas gala modelis ar deviniem neatkarīgiem mainīgiem izskaidroja 61\% izmaiṇu ğimeṇu kopējās vajadzībās. Šajā model̄̄ visstiprākais gimenes vajadzības ietekmējošais faktors izrādījās ǵimenes iekšienē sniegtais atbalsts, kas izskaidroja 8,2\% iznākumu. Kā jau minēts iepriekš, tā ir nozīmīga informācija pakalpojumu, tai skaitā, ārstniecības un rehabilitācijas pakalpojumu sniedzējiem, kuriem būtu jāpievērš pastiprināta uzmanība un vērība tajos gadījumos, kad bērna aprūpētājam nav pieejams atbalsts no citiem ǵimenes locekḷiem.

Interesanti, ka otrs svarīgākais gimenes kopējās vajadzības izskaidrojošais faktors bija uz ğimeni vērsta pakalpojumu sniegšanas principa "Iedrošināšana un sadarbība" ievērošana, savukārt trešais nozīmīgākais izrādījās profesionāly sniegtais atbalsts. Tātad, pakalpojumu sniedzēju atbalsts un uz ğimeni vērstu pakalpojumu sniegšanas principu ievērošana, varētu atstāt pozitīvu ietekmi uz ğimeņu kopējo vajadzību samazināšanos. Šī atkal ir vērtīga informācija pakalpojumu sniedzējiem, kas apliecina, cik nozīmīga loma ir ǵimenes iesaistīšanas ārstēšanas un rehabilitācijas procesos veidam, un pakalpojumu sniedzēju prasmei komunicēt un sadarboties ar klientu. Šie faktori bija nozīmīgāki kopējo gímenes vajadzību mazinātāji, nekā sociālekonomiskie faktori - ǵimenes ienākumu līmenis un bērna primārā aprūpētāja nodarbinātība.

Lai gan ar bērna veselību saistîtie faktori, bija nozīmīgi ğimenes kopējo vajadzību izskaidrošanā, tomēr pārsteidzošā kārtā to individuālā ietekme bija zema. Kopējais asociēto veselības traucējumu skaits izskaidroja 2,5\%, savukārt bērna kustību ierobežojumu līmenis tikai $0,7 \%$ izmaiṇu gimenes kopējās 
vajadzībās. Savukārt, augsts bērna primārā aprūpētāja uztvertais stresa līmenis izrādījās nozīmīgs kopējās ǵimenes vajadzības pastiprinošs faktors, ar augstāku unikālo ietekmi, nekā sociālekonomiskie un ar bērna veselības stāvokli saistītie faktori.

\subsection{2. Ģimenes vajadzības pēc atbalsta izskaidrojošo faktoru analīze}

Izveidotais modelis ar sešiem neatkarīgiem mainīgiem izskaidroja 44\% izmainu gimenes vajadzībās pēc atbalsta. Nav pārsteidzoši, ka faktors ar vislielāko unikālo ietekmi (13,9\%) bija pašas ǵimenes atbalsts - no tuviniekiem saņemtais atbalsts un palīdzība būtiski mazina papildu atbalsta meklēšanas nepieciešamību. Svarīgi atzīmēt arī profesionāļu sniegtā atbalsta ietekmi. Pakalpojumu sniedzēju atbalsts (unikālā ietekme 4,2\%) un uz ǵimeni vērstu pakalpojumu sniegšanas principa "Iedrošināšana un sadarbība" ievērošana (unikālā ietekme 4,5\%) bija nozīmīgi faktori gimenes vajadzību pēc atbalsta mazināšanai. Nākamais svarīgākais šīs vajadzības ietekmējošais faktors bija bērna asociēto veselības traucējumu skaits - tam pieaugot, pieauga vajadzība pēc atbalsta. Pārsteidzoši, bet šis bija vienīgais ar bērnu saistītais faktors, kam bija ietekme uz ǵimenes vajadzību jomu.

Līdzvērtīga ietekme uz gimenes vajadzībām bija tādiem faktoriem, kā bērna primārā aprūpētāja izglīî̄ba un uztvertā stresa līmenis. Augsts uztvertā stresa līmenis un pamatskolas izglītība bija nozīmīgi vajadzības pastiprinoši faktori. Interesanti, ka zemāks vecāku izglītības līmenis līdz šim nav saistīts ar nepieciešamību pēc papildu atbalsta (Almasri, O’Neil \& Palisano, 2014; Hodgetts, Zwaigenbaum \& Nicholas, 2015), savukārt paaugstināta stresa saistība ar pastiprinātu nepieciešamu pēc atbalsta ir atklāta arī citos pētījumos (Dyson, 1997; Farmer et al., 2004; Glenn et al., 2008). 


\subsection{3. Ģimenes finanšu vajadzības izskaidrojošo faktoru analīze}

Gala modelī, kas izskaidroja 53\% izmaiṇu gimenes finanšu vajadzībās, tika iekḷauti seši faktori - divi bērnu ar cerebrālo trieku raksturojošie faktori, trīs gimeni un viens pakalpojumu sniedzējus raksturojošs faktors. Nav pārsteidzoši, ka faktors ar vislielāko unikālo ietekmi (10,8\%) izrādījās ǵimenes ienākumu līmenis - augsts ienākumu līmenis tika identificēts kā spēcīgs gimenes finanšu vajadzības mazinošs faktors. Saprotama ir arī bērna primārā aprūpētāja nodarbinātības ietekme $(3,1 \%)$ - ja kāds no gimenes locekḷiem nestrādā, tas mazina gimenes kopējos ienākumus, un, līdz ar to, finanšu vajadzības var pieaugt. Trešais ǵimeni raksturojošais faktors ar ietekmi uz gimenes finanšu vajadzību samazināšanu izrādījās gimenes iekšejjais atbalsts lielāks gimenes locekḷu sniegtais atbalsts nozīmīgi samazināja ğimenes finanšu vajadzības.

Otrs nozīmīgākais faktors, ar 5,8\% unikālo ietekmi uz gimenes finanšu vajadzībām, bija bērna kustību ierobežojuma līmenis. Arī šis rezultāts nav pārsteidzošs. Situācijā, kad bērnam ir būtiski kustību traucējumi, pieaug gan ārstēšanas un rehabilitācijas izmaksas, gan ir lielāki izdevumi tehnisko palīglīdzekḷu iegādei un mājokḷa pielāgošanai. Bērna kustību ierobežojumu līmenis tiek identificēts kā nozīmīgs ǵimenes finanšu vajadzības ietekmējošs faktors arī citu pētnieku publikācijās (Palisano et al., 2010; Almasri, O’Neil \& Palisano, 2014). Vēl viens bērnu ar cerebrālo trieku raksturojošais faktors ar nozīmīgu ietekmi uz ǵimenes vajadzību pieaugumu izrādījās asociēto veselības traucējumu skaits - lielāks asociēto veselības traucējumu skaits pastiprināja gimenes finanšu vajadzības, tomēr izveidotajā modelī š̄ faktora unikālā ietekme bija zema.

Savukārt atklājums, ka uz ǵimeni vērstu pakalpojumu sniegšanas principu ievērošana var mazināt ǵimenes finanšu vajadzības, zināmā mērā bija 
pārsteigums. Lai gan nesen publicētie Almasri pētījuma rezultāti arī atklāj uz ǵimeni vērstu pakalpojumu pozitīvu ietekmi uz gimeņu finanšu vajadzību samazināšanu (Alamsri, O’Neil \& Palisano, 2014). Jādomā, ka gimenes, kas saņem pakalpojumus, kad ir tikuši ievēroti uz gimeni vērsti pakalpojumu sniegšanas principi, ir apmierinātākas ar pakalpojumiem kopumā, un, iespējams, retāk izvēlas maksas pakalpojumus, tādējādi, samazinot finansiālos izdevumus.

\subsection{4. Ģimenes vajadzības pēc pakalpojumiem izskaidrojošo faktoru analīze}

Izveidotais regresijas gala modelis sastāvēja no septiniem main̄̄gajiem un izskaidroja $52 \%$ izmaiņu ǵimenes vajadzībās pēc publiskajiem pakalpojumiem. Šajā modelī faktors ar vislielāko unikālo ietekmi $(5,8 \%)$ izrādījās bērna komunikācijas traucējumu līmenis - gímenēm, kuru bērniem bija izteiktāki komunikācija traucējumi, pieauga vajadzība pēc valsts un pašvaldības institūciju pakalpojumiem. Pārsteidzoši, bet bērna kustību ierobežojumu līmenim nebija ietekme uz gimenes vajadzībām pēc pakalpojumiem. Mūsu iegūtie rezultāti atšksiras no citu autoru publicētās informācijas, kur bērna funkcionālie ierobežojumi, tai skaitā, kustību traucējumu līmenis, ir nozīmīgs gímenes vajadzības pēc pakalpojumiem ietekmējošs faktors (Farmer et al., 2004; Palisano et al., 2010; Almasri, O’Neil \& Palisano, 2014). Acīmredzot, rehabilitācijas un izglītības pakalpojumi bērniem ar kustību traucējumiem Latvijā ir pieejamāki un labāk attīstīti, nekā pakalpojumi bērniem, kuriem bez kustību traucējumiem ir arī izteikti komunikācijas traucējumi, kas nereti kombinējas ar izziṇas traucējumiem, un, līdz ar to, pieaug nepieciešamība pēc specifiskām izglìtības un rehabilitācijas programmām. 
Otrs svarīgākais gimenes vajadzības pēc pakalpojumiem izskaidrojošais faktors šajā modelī bija bērna socializācija. Bērnudārza vai dienas centra apmeklēšana bija nozīmīgs faktors šo vajadzību samazināšanai. Trešais nozīmīgākais ar 3,5\% unikālo ietekmi izrādījās uz ǵimeni vērstu pakalpojumu sniegšanas principa "Iedrošināšana un sadarbība" ievērošana. Acīmredzot līdzīgi, kā tas bija finanšu vajadzību kontekstā, gimenes, kuras saņem pakalpojumu atbilstoši uz ǵimeni vērstu pakalpojumu sniegšanas principiem, ir apmierinātākas ar saņemtajiem pakalpojumiem, un, līdz ar to, mazinās vajadzības pēc jauniem pakalpojumiem. Arī citu autoru publikācijās tiek atzīmēts, ka uz ǵimeni vērstu pakalpojumu saņemšana mazina ǵimenes vajadzības pēc pakalpojumiem (Palisano et al., 2010; Almasri, O’Neil \& Palisano, 2014).

Interesanti, ka šajā modelī bērna primārā aprūpētāja uztvertais stresa līmenis bija ar nedaudz lielāku unikālo ietekmi uz ǵimenes vajadzībām pēc pakalpojumiem nekā aprūpētāja nodarbinātība vai gimenes ienākumu līmenis. Nodarbinātība un gimenes finanšu stāvoklis nereti tiek identificēti kā faktori, kas ietekmē gimenes vajadzības pēc pakalpojumiem (Farmer et al., 2004; Palisano

et al., 2010; Hodgetts, Zwaigenbaum \& Nicholas, 2015), savukārt informāciju par aprūpētāja stresa ietekmi uz šo vajadzību veidu mums neizdevās atrast. Iespējams personām ar augstāku stresa līmeni ir grūtāk organizēt savu ikdienu un izvirzịt prioritātes, kas negatīvi ietekmē gan personas dzīves kvalitāti, gan arī traucē plānot un organizēt veicamos uzdevumus (Glenn et al., 2009; Wu et al., 2014).

Kā jau iepriekš minēts, vien̄̄gais no identificētajiem ǵimenes vajadzības ietekmējošiem faktoriem ar nozīmīgu ietekmi uz visām apskatītajām ǵimenes vajadzību jomām bija gimenes sniegtais atbalsts. Arī šajā gadījumā lielāks ǵimenes locekḷu sniegtais atbalsts bija nozīmīgs šī veida vajadzību mazinošs 
faktors, lai gan tā unikālā ietekme bija mazāka, nekā citiem modelī iekḷautajiem faktoriem.

\subsection{5. Ģimenes vajadzības pēc informācijas izskaidrojošo faktoru analīze}

Regresijas gala modelis izskaidroja 23\% izmaiņu ǵimenes vajadzībās

pēc informācijas. Šajā modelī visstiprākie vajadzības ietekmējošie faktori bija gimenes ienākumu līmenis un profesionāļu atbalsts. Palielinoties ǵimenes ienākumu līmenim un saņemot lielāku atbalstu no bērna ārstēšanā un apmācībā iesaistītajiem profesionāliem, vajadzība pēc informācijas samazinājās. Vajadzība pēc informācijas samazinājās arī tajos gadījumos, kad tika ievērots uz ǵimeni vērsts pakalpojumu sniegšanas princips "Vispārējās informācijas nodrošināšana", kā arī tad, kad bērna primārais aprūpētājs sañēma tuvinieku atbalstu.

Vienīgais ar bērnu saistītais faktors, kas ietekmēja ğimenes vajadzību pēc informācijas, bija bērna komunikācija - izteikti bērna komunikācijas traucējumi palielināja g̊imenes vajadzību pēc informācijas.

Zemā determinācijas koeficienta vērtība liecina, ka pētījuma laikā nav izdevies identificēt faktorus, kas nozīmīgāk izskaidrotu šo ǵimenes vajadzību veidu. Zemā determinācijas koeficienta vērtība iespējams saistāma arī ar datu analīzes īpatnībām. Tā kā punktu skaits ĢVA informācijas vajadzību jomā neatbilda normālsadalījumam, tas tika logaritmēts, kas iespējams ietekmēja regresijas analīzes rezultātu.

\subsubsection{Kopsavilkums par ǵimenes vajadzības izskaidrojošiem faktoriem}

Pētījumā tika apskatīti seši bērnu ar cerebrālo trieku, desmit ǵimeni, un deviņi rehabilitācijas pakalpojumus raksturojoši faktori, kas, iespējams, ietekmē 
gimenes vajadzības, bet tikai viens no analizētajiem faktoriem - gímenes iekšējais atbalsts - tika identificēts kā nozīmīgs vajadzību ietekmējošs faktors visās apskatītajās ǵimenes vajadzību jomās. Bērna primārajam aprūpētajam būtiski mazinājās paustās vajadzības, ja tika saņemts atbalsts no citiem ǵimenes locekḷiem.

Līdzīgi kā citu autoru ziņojumos (Palisano et al., 2010, Almasri, O’Neil \& Palisano, 2014, Hodgets, Zwaigenbaum \& Nicholas, 2015), arī šajā pētījumā gimenes vajadzību samazinoši faktori izrādījās tādi sociālekonomiskie apstākḷi kā ğimenes ienākumu līmenis, kas bija nozīmīgs vajadzības ietekmējošs faktors četrās apskatītajās vajadzību jomās, kā arī bērna primārā aprūpētāja nodarbinātība ar ietekmi uz trim vajadzību jomām. Savukārt ar bērna veselību saistīto faktoru ietekme bija mazāk nozīmīga - lielāks asociēto veselības traucējumus skaits gan izrādījās vajadzības pastiprinošs apstāklis trīs apskatītajās vajadzību jomās, tomēr tā unikālā ietekme bija zema. Bērna kustību un komunikācijas traucējumi bija vajadzību pastiprinoši faktori tikai divās jomās - izteikti komunikācijas traucējumi palielināja ğimenes vajadzības pēc pakalpojumiem un informācijas, savukārt, ja bērnam bija smagi kustību traucējumi, tas pastiprināja finanšu vajadzības, kā arī kopējās gimenes vajadzības.

Bērna primārā aprūpētāja uztvertā stresa līmenis izrādījās nozīmīgs ietekmējošs faktors trīs vajadzību jomās - augstāks uztvertā stresa līmenis pastiprināja gimenes kopējās vajadzības, kā arī vajadzības pēc pakalpojumiem un atbalsta.

Iepriekš minētie faktori ir unikāli, individuāli un vairumā gadījumu nav tieši ietekmējami. Pakalpojumu sniedzējiem, kuri strādā ar gímenēm, kurās aug pirmsskolas vecuma bērns ar cerebrālo trieku, būtu jāṇem vērā iepriekš minēto faktoru ietekme uz ǵimenes vajadzībām un attiecīgi jāpievērš papildu uzmanība gimenēm ar potenciālu augstāku vajadzību risku. 
Pētījuma rezultātu analīze atklāja nozīmīgu arī to faktoru ietekmi, kas ir tieši atkarīgi no pakalpojumu sniedzējiem. Tā rehabilitācijas pakalpojumu sniegšana atbilstoši uz gimeni vērsta pakalpojuma sniegšanas principam "Iedrošināšana un sadarbība" bija nozīmīgs gimenes vajadzības mazinošs faktors četrās vajadzību jomās - kopējās ǵimenes vajadzības, vajadzības pēc atbalsta, pakalpojumiem un finansiāla atbalsta. Savukārt, ja ǵimene saṇēma lielāku atbalstu no profesionāliem, tas bija nozīmīgs vajadzību mazinošs apstāklis trīs vajadzību jomās.

Kopumā jāsecina, ka nozīmīgākie vajadzību ietekmējošie faktori Latvijā dzīvojošām ǵimenēm ir saistīti ar sociālekonomiskiem apstākḷiem un līdzcilvēku atbalstu - vai tie ir ǵimenes locekḷi, vai profesionāḷi, kuri strādā ar gimeni. Savukārt bērna funkcionēšanas ierobežojumi un veselības stāvoklis ir mazāk nozīmīgi vajadzību ietekmējoši faktori.

\subsection{Metodoloǵiskā analīze un pētījuma ierobežojumi}

Izvirzịtā pētījuma mērķa sasniegšanai tika izvēlēts analītisks viena momenta (šksērsgriezuma) pētījuma dizains. Tādējādi tika iegūta informācija par Latvijā dzīvojošo ǵimeņu, kas audzina pirmsskolas vecuma bērnus ar cerebrālo trieku, vajadzībām un tās ietekmējošiem faktoriem konkrētā laika periodā. Lai varētu apgalvot, ka pētījumā apkopotā informācija ir vispārināma arī attiecībā uz citu laika periodu, būtu jāveic atkārtota datu ieguve, kas netika ieplānots. Līdz ar to, iegūtā informācija par Latvijā dzīvojošo gimeņu vajadzībām un faktoriem, kas to ietekmē, jāvērtē un jāinterpretē piesardzīgi, neizslēdzot iespējamās izmaiņas laikā.

Ģimeņu vajadzības tika noskaidrotas, izmantojot standartizētu aptaujas anketu "Ģimenes vajadzību aptauja", kas datu ieguves periodā bija atzītākā un publikācijās visplašāk pielietotā aptaujas anketa ǵimeņu vajadzību identificēšanai. Anketa tika izstrādāta, lai apzinātu to ǵimeņu vajadzības, kas 
audzina tieši pirmsskolas vecuma bērnus ar attīstības traucējumiem. Tomēr jāṇem vērā, ka anketa ir izstrādāta vairākus desmitus gadus atpakaḷ un, lai gan datu ieguvei tika izmatota tās modificētā un papildinātā versija, tomēr ir iespējams, ka netika apzinātas visas aktuālās vajadzības, kādas izjūt Latvijā dzīvojoša gimene, kura audzina bērnu ar cerebrālo trieku. Standartizētu aptaujas anketu izmantošanas priekšrocība ir datu ieguves vienkāršība un iespēja veikt datu analīzi, pielietojot kvantitatīvās datu analīzes metodes. Tomēr šāda datu ieguve nel̦auj problēmu pētīt padziḷināti, tādēḷ būtu ieteicams pētījumā iegūto kvantitatīvo informāciju papildināt ar padziļinātu izpēti, izmantojot kvalitatīvās datu ieguves un analīzes metodes.

Iespējamie ǵimenes vajadzību ietekmējošie faktori tika identificēti balstoties uz visaptverošu literatūras izpēti par faktoriem, kas var ietekmēt gimenes vajadzības gadījumos, ja ǵimenes aprūpē ir bērns ar attīstības traucējumiem. Vajadzības gimenēs, kurās aug bērns ar attīstības traucējumiem, ir plaši pētītas, tomēr pētījuma sagatavošanās posmā mums neizdevās atrast avotus, kuros būtu apskatītas ǵimeņu vajadzības mums pietuvinātā ǵeopolitiskā regiionā ar līdzīgu vēsturisko un sociālekonomisko pieredzi. Līdz ar to mums, iespējams, nebija izdevies identificēt tos vajadzību veidus vai iespējamos ietekmējošos faktorus, kas ir unikāli tieši mūsu regionā. Par to liecina arī daudzfaktoru lineārās regresijas rezultāti - gala modeḷi izskaidroja no 23\% līdz $61 \%$ izmaiṇu ǵimeṇu vajadzīibās. Tātad, varētu būt vēl citi neparedzēti un neidentificēti faktori, kas varētu ietekmēt Latvijā dzīvojošu ğimeņu vajadzības. To identificēšanai mērķtiecīgāk būtu izmantot kvalitatīva pētījuma dizainu, kas ļautu padziḷināti izprast pētāmo problēmu un izvirzīt jaunas hipotēzes.

Ģimenes vajadzību ietekmējošie faktori tika noskaidroti, izmantojot daudzfaktoru lineārās regresijas analīzes metodi. Šāds analīzes veids tika izvēlēts, jo l̦auj pētît interesējošās pazīmes atkarību no vairākām neatkarīgām pazīmēm, un pētījumā iegūtie dati atbilda nosacījumiem, kas nepieciešami daudzfaktoru lineārās regresijas veikšanai. Tomēr ir zināms, ka ne visiem 
neatkarīgajiem main̄̄giem ir tieša ietekme uz atkarīgo pazīmi (Palisano et al., 2010), tādēḷ labākai pētāmās problēmas izpratnei turpmākos pētījumos varētu pievērst pastiprinātu uzmanību identificēto, un, iespējams, jaunu faktoru, pastarpinātajām ietekmēm. 


\section{SECINĀJUMI}

1. Latvijā dzīvojošu pirmsskolas vecuma bērnu ar cerebrālo trieku ǵimenes uzskata, ka tām trūkst informācijas par ǵimenei svarīgiem jautājumiem, īpaši norādot, ka ir nepietiekami informētas par pakalpojumiem, kas ir pieejami viṇu bērnam, kā arī par bērna izglītības iespējām.

2. Aptaujātās gimenes izjūt nepietiekamu rehabilitācijas pakalpojumu nodrošinājumu, kā arī atzīmē neefektīvu rehabilitācijas, izglīīîbas un sociālo pakalpojumu koordināciju.

3. Pētījuma rezultāti liecina, ka valsts garantētais finansējums nav pietiekams bērnu ar cerebrālo trieku ārstēšanai un rehabilitācijai - vairumam ǵimeņu bērna ārstēšanai un rehabilitācijai ir nepieciešams finansiāls atbalsts.

4. Daļa aptaujāto ǵimeņu, kas audzina bērnu ar cerebrālo trieku, atzīmē psihologískā un morālā atbalsta trūkumu.

5. Pētījuma rezultātā apstiprinājās darba hipotēze, ka bērnu ar cerebrālo trieku gímeņu vajadzības ietekmē gimeni, bērnu ar cerebrālo trieku un rehabilitācijas pakalpojumu sniedzējus raksturojoši faktori, un šo faktoru unikālā ietekme ir atkarīga no gimenes vajadzību veida. Pēc regresijas analīzes modeḷiem, Latvijā dzīvojošo pirmsskolas vecuma bērnu ar cerebrālo trieku gimeņu:

- kopējās vajadzības vislabāk izskaidro saņemtais atbalsts no citiem ǵimenes locekḷiem. Kā nākamie nozīmīgākie izskaidrojošie faktori ir gimenes ienākumu līmenis, bērna primārā aprūpētāja nodarbinātība, uztvertā stresa līmenis un saņemtais atbalsts no profesionāļiem, kā arī sadarbības principu ievērošana pakalpojumu sniegšanā, un asociēto veselības traucējumu skaits, savukārt bērna kustību ierobežojumu līmenis tās izskaidro pavisam nedaudz.

- vajadzību pēc pakalpojumiem vislabāk izskaidro bērna socializācija, komunikācijas ierobežojumu līmenis un bērna primārā aprūpētāja 
uztvertā stresa līmenis. Nedaudz mazākā mērā tās izskaidro gimenes ienākumu līmenis un bērna primārā aprūpētāja nodarbinātîba, kā arī saņemtais atbalsts no citiem gimenes locekliem, un sadarbības principu ievērošana pakalpojumu sniegšanā.

- finanšu vajadzības vispilnīgāk izskaidro gimenes ienākumi un bērna kustību ierobežojumu līmenis. Nedaudz mazāk tās izskaidro bērna primārā aprūpētāja nodarbinātîba, sadarbības principu ievērošana pakalpojumu sniegšanā un saņemtais atbalsts no citiem ǵimenes locekḷiem, kā arī asociēto veselības traucējumu skaits.

- vajadzību pēc atbalsta vislabāk izskaidro saņemtais atbalsts no citiem gimenes locekḷiem, mazākā mērā tās izskaidro no profesionāļiem saņemtais atbalsts un sadarbības principu ievērošana pakalpojumu sniegšanā, bērna primārā aprūpētāja izglītības un uztvertā stresa līmenis, kā arī asociēto veselības traucējumu skaits.

- $\quad$ vajadzību pēc informācijas vienlīdz nozīmīgi izskaidro tādi faktori kā saņemtais atbalsts no profesionāḷiem un citiem gimenes locekḷiem, vispārējās informācijas sniegšanas principu ievērošana pakalpojumu sniegšanā, ienākumu līmenis, kā arī bērna komunikācijas ierobežojumu līmenis.

6. Daļa faktoru, kas izskaidro Latvijā dzīvojošo ǵimeņu vajadzības, vēl joprojām nav zināmi.

7. Kopumā pêtījuma rezultāti atklāj, ka nozīmīgākie vajadzību ietekmējošie faktori Latvijā dzīvojošām ğimenēm ir saistīti ar sociālekonomiskiem apstākḷiem, kā arī līdzcilvēku un profesionāḷu atbalstu. Savukārt rehabilitācijas pakalpojumu pieejamība un saņemšanas kārtība, kā arī bērna funkcionēšanas ierobežojumi un veselības traucējumi, ir mazāk nozīmīgi faktori. 


\section{ORGANIZATORISKIE IETEIKUMI}

1. Bērnu ar cerebrālo trieku mērķtiecīgai un koordinētai ārstēšanai un rehabilitācijai, kā arī atbalsta nodrošināšanai visai ǵimenei Latvijā ir jāveido sistēma, kas ļautu koordinēt bērna ārstēšanai un attīstībai nepieciešamos, dažādas pakḷautības resoru sniegtos, pakalpojumus, kā arī nodrošināt nepieciešamo atbalstu un informāciju gimenei. Šāds atbalsts ir jānodrošina, sākot no slimības diagnozes noteikšanas brīža.

2. Pētījuma rezultāti atklāj profesionāḷu, tai skaitā rehabilitācijas speciālistu, sniegtā atbalsta nozīmi gimenes vajadzību mazināšanā. Tādēḷ bērna ārstēšanas un rehabilitācijas procesā ir svarīga ne tikai atbilstošu medicīnisko tehnologiju pielietošana, bet arī cilvēcisks atbalsts bērna aprūpētājiem, kā ar̄̄ uz ǵimeni vērstu pakalpojumu sniegšanas principu ievērošana. Rehabilitācijas speciālistu izglīitības programmās būtu jāiekḷauj apmācību cikli, kas attīsta speciālistu prasmes sniegt psiholoǵisku atbalstu, un realizēt uz ǵimeni vērstu ārstēšanas un rehabilitācijas pieeju.

3. Ārstniecības un rehabilitācijas, kā arī izglītības un sociālo pakalpojumu sniedzējiem, ir svarīgi iegūt informāciju par pieejamo atbalstu gimenes iekšienē. Gadījumā, ja bērna primārajam aprūpētājam nav pieejams tuvinieku atbalsts, ǵimenei ir jāvelta pastiprināta uzmanība un atbalsts.

4. Tā kā pētījums rezultāti norāda uz apgrūtinātu rehabilitācijas un pirmsskolas izglītības pakalpojumu pieejamību tieši bērniem ar izteiktiem komunikācijas traucējumiem, tad pastiprināti ir jāveido rehabilitācijas programmas, kas piemērotas bērniem ar cerebrālo trieku, kuriem bez kustību traucējumiem novēro arī komunikācijas traucējumus. 


\section{IZMANTOTĀ LITERATŪRA}

Avoti

1. Centrālā statistikas pārvalde, 2013.

2. Starptautiskās statistiskās slimību un veselības problēmu klasifikācijas 10.redakcija (SSK-10).

Literatūra un periodiskie izdevumi

3. Almasri, N.A., Palisano, R.J., Dunst, C.J., Chiarello, L.A., O'Neil, M. E., Polansky, M. Determinants of needs of families of children and youth with cerebral palsy. Children's Health Care. 2011, 40(2), 130-154.

4. Almasri, N.A., O’Neil, M., Palisano, R.J. Predictors of needs for families of children with cerebral palsy. Disability and rehabilitation. 2014, 36(3), 210219.

5. Bailey, D.B., \& Simeonsson, R.J. Assessing needs of families with handicapped infants. The Journal of Special Education 1988, 22(1), 117-127.

6. Bailey Jr, D. B., Skinner, D., Correa, V., Arcia, E., Reyes-Blanes, M. E., Rodriguez, P. et alNeeds and supports reported by Latino families of young children with developmental disabilities. American Journal on Mental Retardation. 1999, 104(5), 437-451.

7. Bamm, E.L., \& Rosenbaum, P. Family-centered theory: origins, development, barriers, and supports to implementation in rehabilitation medicine. Archives of physical medicine and rehabilitation. 2008, 89(8), 1618-1624.

8. Bax, M., Tydeman, C., Flodmark, O. Clinical and MRI correlates of cerebral palsy: the European Cerebral Palsy Study. Jama 296.13 (2006): 1602-1608. Iegūts no: http://jamanetwork.com/journals/jama/fullarticle/203508 [sk.15.06.2016.].

9. Bērtule D., Vētra A. Aptaujas anketu „Aprūpes procesa novērtējums” un „Ģimenes vajadzību aptauja” adaptācija latviešu valodā. RSU zinātniskie raksti. 2012, 79-86.

10. Broderick, C.B. Understanding family process: Basics of family systems theory. Sage. 1993. Via GoogleBooks.

11. Bronfenbrenner, U. Ecology of the family as a context for human development: Research perspectives. Developmental psychology. 1986, 22(6), 723.

12. Brossard-Racine, M., Hall, N., Majnemer, A., Shevell, M. I., Law, M., Poulin, C., Rosenbaum, P. Behavioural problems in school age children with cerebral palsy. European Journal of Paediatric Neurology. 2012, 16(1), 35-41.

13. Bruder, M.B. Family-centered early intervention clarifying our values for the new millennium. Topics in early childhood special education. 2000, 20(2), $105-115$.

14. Buran, C.F., Sawin, K., Grayson, P., Criss, S. Family needs assessment in cerebral palsy clinic. Journal for Specialists in pediatric Nursing. 2009, 14(2), 86-93. 
15. Campanozzi, A., Capano, G., Miele, E., Romano, A., Scuccimarra, G., Del Giudice, E., et al. Impact of malnutrition on gastrointestinal disorders and gross motor abilities in children with cerebral palsy. Brain and Development. 2007, 29(1), 25-29.

16. Caicedo, C. Families with special needs children: family health, functioning, and care burden. Journal of the American Psychiatric Nurses Association. 2014, 20(6), 398-407.

17. Cantwell, J., Muldoon, O.T., Gallagher, S. Social support and mastery influence the association between stress and poor physical health in parents caring for children with developmental disabilities. Research in developmental disabilities. 2014, 35(9), 2215-2223.

18. Darrah, J., Wiart, L., Magill-Evans, J., Ray, L., Andersen, J. Are familycentred principles, functional goal setting and transition planning evident in therapy services for children with cerebral palsy? Child: care, health and development. 2012, 38(1), 41-47.

19. Dempsey, I., \& Keen, D. A review of processes and outcomes in familycentered services for children with a disability. Topics in Early Childhood Special Education. 2008, 28(1), 42-52.

20. Dunst, C.J., \& Dempsey, I. Family-professional partnerships and parenting competence, confidence, and enjoyment. International Journal of Disability, Development and Education. 2007, 54(3), 305-318.

21. Dunst, C.J., \& Trivette, C.M. Meta-analytic structural equation modeling of the influences of family-centered care on parent and child psychological health. International journal of pediatrics. 2009. Iegūts no http://dx.doi.org/10.1155/2009/576840 [sk.5.05.2016].

22. Dyson, L.L. Fathers and mothers of school-age children with developmental disabilities: Parental stress, family functioning, and social support. American journal on mental retardation. 1997, 102(3), 267-279.

23. Eddy, L.L., \& Engel, J.M. The impact of child disability type on the family. Rehabilitation Nursing. 2008, 33(3), 98-103.

24. Ellis, J.T., Luiselli, J.K., Amirault, D., Byrne, S., O'Malley-Cannon, B., Taras, M., et al. Families of children with developmental disabilities: assessment and comparison of self-reported needs in relation to situational variables. Journal of Developmental and Physical Disabilities. 2002, 14(2), 191-202.

25. Espe - Sherwindt M.. Family-centred practice: collaboration, competency and evidence. Support for learning. 2008, 23(3), 136-143.

26. Farmer, J.E., Marien, W.E., Clark, M.J., Sherman, A., Selva, T.J. Primary care supports for children with chronic health conditions: Identifying and predicting unmet family needs. Journal of Pediatric Psychology. 2004, 29(5), 355-367.

27. Glenn, S., Cunningham, C., Poole, H., Reeves, D., Weindling, M. Maternal parenting stress and its correlates in families with a young child with cerebral palsy. Child: care, health and development. 2009, 35(1), 71-78.

28. Granild-Jensen, J.B., Rackauskaite, G., Flachs, E.M., Uldall, P. Predictors for early diagnosis of cerebral palsy from national registry data. Developmental Medicine \& Child Neurology. 2015, 57(10), 931-935. 
29. Graves C., Hayes V.E. Do nurses and parents of children with chronic conditions agree on parental needs? Journal of Pediatric Nursing. 1996, 11(5), 288-299.

30. Hidecker, M.J.C., Paneth, N., Rosenbaum, P.L., Kent, R.D., Lillie, J., Eulenberg, J. B., et al. Developing and validating the Communication Function Classification System for individuals with cerebral palsy. Developmental Medicine \& Child Neurology, 2011, 53(8), 704-710.

31. Hidecker, M.J.C., Cunningham, B.J., Thomas-Stonell, N., Oddson, B., Rosenbaum, P. Validity of the Communication Function Classification System for use with preschool children with communication disorders. Developmental Medicine \& Child Neurology. 2017, 59(5), 526-530.

32. Himmelmann, K., \& Uvebrant, P. The panorama of cerebral palsy in Sweden. XI. Changing patterns in the birth-year period 2003-2006. Acta paediatrica. 2014, 103(6), 618-624.

33. Hodgetts, S., Zwaigenbaum, L., \& Nicholas, D.. Profile and predictors of service needs for families of children with autism spectrum disorders. Autism. 2015, 19(6), 673-683.

34. Jeglinsky, I., Autti-Rämö, I., \& Brogren Carlberg, E. Two sides of the mirror: parents' and service providers' view on the family-centredness of care for children with cerebral palsy. Child: care, health and development. 2012, 38(1), 79-86.

35. Johnston, M.V., \& Hagberg, H. Sex and the pathogenesis of cerebral palsy. Developmental Medicine \& Child Neurology. 2007, 49(1), 74-78.

36. Kancherla, V., Amendah, D.D., Grosse, S.D., Yeargin-Allsopp, M., Braun, K.V.N. Medical expenditures attributable to cerebral palsy and intellectual disability among Medicaid-enrolled children. Research in developmental disabilities, 2012, 33(3), 832-840.

37. King, S., King, G., Rosenbaum, P. Evaluating Health Service Delivery to Children With Chronic Conditions and Their Families: Development of a Refined Measure of Processes of Care (MPOC-20). Children's Health Care. 2004, 33(1), 35-57.

38. King S, Teplicky R, King G, Rosenbaum P. Family - centred service for children with cerebral palsy and their families: A rewiew of the literature. In Seminars in pediatric neurology. WB Saunders. 2004, 11(1), 78-86.

39. Kruse, M., Michelsen, S. I., Flachs, E. M., Brønnum-hansen, H., Madsen, M., Uldall, P. Lifetime costs of cerebral palsy. Developmental Medicine \& Child Neurology. 2009, 51(8), 622-628.

40. Kuhlthau, K.A., Bloom, S., Van Cleave, J., Knapp, A.A., Romm, D., Klatka, K., et al. Evidence for family-centered care for children with special health care needs: a systematic review. Academic pediatrics. 2011, 11(2), 136-143.

41. Kuo, D.Z., Mac Bird, T., Tilford, J.M. Associations of family-centered care with health care outcomes for children with special health care needs. Maternal and child health journal. 2011, 15(6), 794-805.

42. Law, M., Hanna, S., King, G., Hurley, P., King, S., Kertoy, M., Rosenbaum, P. Factors affecting family-centred service delivery for children with disabilities. Child: care, health and development. 2003, 29(5), 357-366. 
43. Lindley, L.C., \& Mark, B.A. Children with special health care needs: Impact of health care expenditures on family financial burden. Journal of child and family studies. 2010, 19(1), 79-89.

44. Lipscombe, B., Boyd, R.N., Coleman, A., Fahey, M., Rawicki, B., Whittingham, K. Does early communication mediate the relationship between motor ability and social function in children with cerebral palsy?. Research in developmental disabilities. 2016, 53, 279-286.

45. McMahon M., Pruitt D., Vargus-Adams J. Cerebral palsy. in Pediatric Rehabilitation: Principles and Practice 5th Edition. Alexander M.A., Matthews D.J., eds. Demos Medical Publishing. 2015, 340-357.

46. Mei, C., Reilly, S., Reddihough, D., Mensah, F., Pennington, L., Morgan, A. Language outcomes of children with cerebral palsy aged 5 years and 6 years: a population-based study. Developmental Medicine \& Child Neurology, 2016, 58(6), 605-611.

47. Murphy, N., Caplin, D.A., Christian, B.J., Luther, B.L., Holobkov, R., Young, P.C. The function of parents and their children with cerebral palsy. $P M \& R$. 2011, 3(2), 98-104.

48. Nitta, O., Taneda, A., Nakajima, K., Surya, J. The relationship between the disabilities of school-aged children with cerebral palsy and their family needs. Journal of Physical Therapy Science. 2005, 17(2), 103-107.

49. Novak, I., Hines, M., Goldsmith, S., Barclay, R. Clinical prognostic messages from a systematic review on cerebral palsy. Pediatrics, peds-2012. 2012. Iegūts no: Www.pediatrics.org/cgi/doi/10.1542/peds.2012-0924. [sk.11.02.2016].

50. Pakula, A.T., Braun, K.V.N., Yeargin-Allsopp, M. Cerebral palsy: classification and epidemiology. Physical medicine and rehabilitation clinics of North America. 2009, 20(3), 425-452.

51. Palisano, R.J., Almarsi, N., Chiarello, L.A., Orlin, M.N., Bagley, A., Maggs, J. Family needs of parents of children and youth with cerebral palsy. Child: care, health and development. 2010, 36(1), 85-92.

52. Palisano, R., Rosenbaum, P., Walter, S., Russell, D., Wood, E., Galuppi, B. Development and reliability of a system to classify gross motor function in children with cerebral palsy. Developmental Medicine \& Child Neurology. 1997, 39(4), 214-223.

53. Parkes, J., Caravale, B., Marcelli, M., Franco, F., Colver, A. Parenting stress and children with cerebral palsy: a European cross-sectional survey. Developmental Medicine \& Child Neurology. 2011, 53(9), 815-821.

54. Pehora, C., Gajaria, N., Stoute, M., Fracassa, S., Serebale-O'Sullivan, R., \& Matava, C. T. Are parents getting it right? A survey of parents' internet use for children's health care information. Interactive journal of medical research. 2015, 4(2). Iegūts no: doi: 10.2196/ijmr.3790. [sk. 5.06.2017].

55. Perrin, E. C., Lewkowicz, C., Young, M. H. Shared vision: concordance among fathers, mothers, and pediatricians about unmet needs of children with chronic health conditions. Pediatrics. 2000, 105(Supplement 2), 277-285.

56. Piškur, B., Beurskens, A.J., Ketelaar, M., Jongmans, M.J., Casparie, B.M., Smeets, R.J. Daily actions, challenges, and needs among Dutch parents while supporting the participation of their child with a physical disability at home, at 
school, and in the community: a qualitative diary study. BMC Pediatrics. 2017, 17(1), 12.

57. Pousada M., Guillamón N., Hernández-Encuentra E., Muñoz, E., Redolar, D., Boixadós, M., Gómez-Zúñiga, B. Impact of caring for a child with cerebral palsy on the quality of life of parents: a systematic review of the literature. Journal of Developmental and Physical Disabilities. 2013, 25(5), 545-577.

58. Rosenbaum, P. Family and quality of life: key elements in intervention in children with cerebral palsy. Developmental Medicine \& Child Neurology. 2011, 53(s4), 68-70.

59. Sloper, P., \& Turner, S. Service needs of families of children with severe physical disability. Child: care, health and development. 1992, 18(5), 259282.

60. Ueda, K., Bailey, D., Yonemoto, N., Kajikawa, K., Nishigami, Y., Narisawa, S., et al. Validity and reliability of the Family Needs Survey-Japanese version. Journal of policy and practice in intellectual disabilities. 2013, 10(2), 178-179. Iegūts no: https://doi.org/10.1016/j.ridd.2013.07.024. [sk. 11.02.2016].

61. Wang, P., \& Michaels, C.A. Chinese families of children with severe disabilities: Family needs and available support. Research and Practice for Persons with Severe Disabilities. 2010, 34(2), 21-32.

62. Ziviani, J., Darlington, Y., Feeney, R., Rodger, S., Watter, P. Early intervention services of children with physical disabilities: Complexity of child and family needs. Australian occupational therapy journal. 2014, 61(2), $67-75$.

Interneta resursi

63. "Bērnu ar invaliditāti rehabilitācijas efektivitāte Latvijā: sociālantropolog̣iskais aspekts", 2016. Iegūts no:

http://www.tiesibsargs.lv/uploads/content/bernu_ar_invaliditati_rehab_lv_soci alantropologija_1486044337.pdf [sk.1.02.2018].

64. RD Labklājības departaments. Sociālās rehabilitācijas programmas bērniem ar funkcionāliem ierobežojumiem. Iegūts no: http://www.ld.riga.lv/lv/socialiepakalpojumi-49/socialas-rehabilitacijas-un-islaicigas-socialas-aprupespakalpojumi-berniem.html [sk.5.07.2017].

65. WHO, Process of translation and adaptation of instruments. Iegūts no: http://www.who.int/substance_abuse/research_tools/translation/en/ [sk. 14.01.2012]. 


\section{PUBLIKĀCIJAS UN ZIN̦OJUMI PAR PĒTĪJUMA TĒMU}

\section{Publikācijas}

1. Bērtule, D., Vētra, A. Aptaujas anketu „Aprūpes procesa novērtējums” un "Ģimenes vajadzību aptauja" latviešu valodas tulkojuma psihometriskie rādītāji. RSU zinātniskie raksti. 2012, II sējums, 79-86.

2. Bērtule, D., Vētra A. Ģimenes, kurā ir pirmsskolas vecuma bērns ar cerebrālo trieku, specifiskās vajadzības. RSU zinātniskie raksti. 2013, 224 231.

3. Bertule, D., \& Vetra, A. The family needs of parents of preschool children with cerebral palsy: The impact of child's gross motor and communications functions. Medicina, 2014, 50(6), 323-328.

4. Bērtule, D., Vētra A. Pirmsskolas vecuma bērna ar cerebrālo trieku kustību traucējuma līmen̦a saistība ar gimenes specifiskajām vajadzībām, $R S U$ zinātniskie raksti. 2014, 206-214.

5. Bērtule, D., Vētra A. Vecāku apmierinātība ar rehabilitācijas pakalpojumiem bērniem ar cerebrālo trieku. RSU zinātniskie raksti. 2015, $266-272$.

6. Bertule, D., \& Vetra, A. Predictors of needs for community and financial resources for families of pre-school children with cerebral palsy. In SHS Web of Conferences. 2016, Vol. 30, 00041.

\section{Konferenču tēzes un prezentācijas}

1. Bērtule, D., Vētra, A. Specifiskās vajadzības ǵimenēs ar bērnu ar īpašām vajadzībām: "Ģimenes vajadzību aptaujas" validācija latviešu valodā. $R S U$ Zinātniskā konference. 2012: tēzes un stenda referāts. 
2. Bērtule, D., Vētra, A. Rehabilitācijas pakalpojumi pacientu vecāku skatījumā: "Aprūpes procesa novērtējuma" validācija latviešu valodā. $R S U$ Zinātniskā konference. 2012: tēzes un mutiska prezentācija.

3. Bertule, D., Vetra, A. The impact of family-centered practice on family needs of parents of children with neurodevelopmental disorders. 24th Annual Meeting of European Academy of Childhood Disability (EACD). Istanbul, 2012, 16-19 May: abstract and poster presentation.

4. Bertule, D., Vetra A. The unmet family needs and perceived stress in parents with children with cerebral palsy. 4th International Cerebral Palsy Conference. Pisa, 2012, 10-13 October: abstract and oral presentation.

5. Bertule D, Vetra A. The family needs and perceived stress in parents with children with neurodevelopmental disorders. Society.Health.Welfare. Riga, 2012, 22-23 November: abstract and oral presentation.

6. Bērtule, D., Vētra, A. Funkcionēšanas ierobežojumi 2-7 gadus veciem bērniem ar cerebrālo trieku. RSU Zinātniskā konference: tēzes un stenda referāts. 2013, 177.

7. D.Bērtule, A.Vētra. Ģimenes, kurā ir pirmsskolas vecuma bērns ar cerebrālo trieku, specifiskās vajadzības. RSU Zinātniskā konference. 2013: tēzes un mutiska prezentācija.

8. Bertule, D., Vetra A. Inter - relationship between gross motor function, manual ability and communication function classification systems in pre school children with cerebral palsy. 3rd Baltic and North Sea Conference on Physical and Rehabilitation Medicine. Hannover, 2013, 25-28 September: abstract and oral presentation.

9. Bertule D, Vetra A. The impact of child's communication function on family needs of parents of children with cerebral palsy. 25th Annual Meeting of the European Academy of Childhood Disability (EACD). Newcastle, 2013, 10-12 October: abstract and poster presentation. 
10. Bērtule, D., Vētra, A.. Pirmsskolas vecuma bērna ar cerebrālo trieku kustību ierobežojuma līmeņa saistība ar gimenes specifiskajām vajadzībām. RSU Zinātniskā konference. 2014: tēzes un mutiska prezentācija.

11. Bertule, D., Vetra, A. The impact of family income on family needs of parents of children with cerebral palsy. 26th Annual Meeting of the European Academy of Childhood Disability (EACD). Vienna, 2014, 3-5 July: abstract and poster presentation.

12. Bērtule, D., Vētra, A. Vecāku apmierinātība ar rehabilitācijas pakalpojumiem bērniem ar cerebrālo trieku. RSU Zinātniskā konference. 2015: tēzes un mutiska prezentācija.

13. Bertule, D., Vetra, A. Inter-relationship between gross motor and communication function classification systems in pre-school children with cerebral palsy. 27th Annual Meeting of the European Academy of Childhood Disability (EACD). Copenhagen, 2015, 27-30 May: abstract and poster presentation.

14. Bērtule, D., Vētra, A.Rehabilitācijas pakalpojumi bērnu ar cerebrālo trieku vecāku skatījumā: "Aprūpes procesa novērtējums". RSU Zinātniskā konference. 2016: tēzes un mutiska prezentācija.

15. Bertule, D., Vetra, A. Family-centred care for children with cerebral palsy in Latvia. International Conference on Cerebral Palsy and other Childhoodonset Disabilities: Joint Meeting of: 28th Annual Meeting of the European Academy of Childhood Disability (EACD), 5th International Conference of Cerebral Palsy (ICPC) and 1st Meeting of the International Alliance of Academies of Childhood Disability (IAACD). Stockholm, 2016, 1-4 June: abstract and poster presentation.

16. Bertule, D., Vetra, A. Predictors of needs for community and financial resources for families of pre-school children with cerebral palsy. 29th Annual Meeting of the European Academy of Childhood Disability (EACD). Amsterdam, 2017, 17-20 May: abstract and poster presentation. 


\section{PATEICĪBAS}

Vislielākais paldies mana darba vadītājai asociētai profesorei Anitai Vētrai par ieguldīto darbu, sapratni un atbalstu promocijas darba izstrādē.

Sirsnīgi pateicos visām pētījumā iesaistītajām ǵimenēm par atsaucību un atvēlēto laiku. Milzīgs paldies bērniem par pacietību un drosmi.

Vēlos izteikt vissirsnīgāko pateicību biedrības "Mēs esam līdzās" valdes priekšsēdētājai Andrai Greitānei, biedrības "Latvijas Bērniem ar kustību traucējumiem" valdes priekšsēdētājai Ilzei Kennei un Nacionālā rehabilitācijas centra "Vaivari" bērnu internās rehabilitācijas programmas vadītājai Ivetai Spruǵevicai par atsaucību un atbalstu pētījuma sagatavošanas un praktiskās norises realizācijā.

Paldies Rehabilitācijas katedras kolēǵiem. Īpaši vēlos pateikties asociētai profesorei Signei Tomsonei, docentei Dainai Šmitei un asistentei Gunai Bērziņai par iedrošinājumu, padomiem un pamudinājumiem.

Sisrn̄̄gi pateicos Irēnai Rogovskai par vērtīgājiem padomiem un palīdzību datu apstrādē, kā arī vienmēr sniegtajiem uzmundrinājumiem un atbalstu.

Vislielākais un sirsnīgākais paldies manai g̊imenei par izturību, pacietību un atbalstu.

Paldies visiem, kas šo gadu garumā bija ar mani kopā un mani atbalstīja. 